\title{
Integrated effects of bacteria and fungi biofertilizers on morphological traits, antioxidants indices, and polyphenol compounds of quinoa (Chenopodium quinoa Willd.) under salinity condition
}

Giti Karimi

Urmia University

Latifeh Pourakbar ( I.pourakbar@urmia.ac.ir)

Urmia University

Sina Siavash Moghaddam

Urmia University

Jelena Popović-Djordjević

University of Belgrade

\section{Research Article}

Keywords: salinity, biofertilizer, morphological traits, polyphenol compounds, quinoa

Posted Date: December 10th, 2020

DOl: https://doi.org/10.21203/rs.3.rs-123080/v1

License: (c) (1) This work is licensed under a Creative Commons Attribution 4.0 International License.

Read Full License 


\section{Abstract}

It is imperative to assess the potential of halophyte plant species, such as quinoa, in resisting high salinity levels in arid and semi-arid regions where the productivity of crops is dramatically affected. A factorial experiment based on a completely randomized design with three replications was conducted to explore the effect of integrated biofertilizer, on morphological traits, antioxidants, and polyphenol compounds of quinoa under salinity stress. The studied factors included $\mathrm{NaCl}$ salinity stress at three levels of 0,150 , and $300 \mathrm{mM}\left(S_{0}, S_{150}\right.$, and $S_{300}$, respectively), Trichoderma $(T)$ fungus at two levels (its use and non-use), and biofertilizer at three levels (control, nitrogen $\left(F_{N}\right)$, and phosphorus $\left(F_{P}\right)$. The means of the studied traits showed that the highest shoot length and dry weight was related to $S_{0} T_{0} F_{N}$, the highest root length to $S_{150} T F_{N}$, the highest root dry weight to $S_{0} T_{0} F_{N}$, and the highest phenol and flavonoid contents to $S_{300} T_{F}$ and $S_{0} T F_{N}$ treatments. Among polyphenols, the highest caffeic acid, rutin, coumaric acid, and quercetin were observed in $\mathrm{S}_{0} \mathrm{TF}_{\mathrm{P}}$ and the highest levels of chlorogenic, rosmarinic, cinnamic acids, and apigenin $\left(\mathrm{mg} / \mathrm{kg}\right.$ ) were observed in $\mathrm{S}_{0} \mathrm{TF}_{\mathrm{N}}$. To sum up, Bacteria and fungi biofertilizers were effective on the studied traits at the three salinity levels.

\section{Introduction}

Quinoa (Chenopodium quinoa willd) is an annual dicotyledon pseudocereal from the sub-family spinach that is native to South America and the Andes where its cultivation dates back to thousands of years ago and it is used as an essential source of nutrient ${ }^{67}$. The young leaves of quinoa are consumed fresh as a leafy vegetable like spinach ${ }^{45}$. It is also used as an ingredient in the recipes of many foods. The seeds of quinoa are rich in free gluten and nutritional value, and their protein content is greater than corn and wheat. They also contain a great deal of methionine and lysine when compared to cereals ${ }^{37}$. Quinoa is also known as a halophyte cereal that is more resistant to environmental stresses, including salinity and water deficit, than barley, wheat, and corn ${ }^{25,56}$.

Saline soils severely inhibit crop growth and soil productivity ${ }^{43}$. The best approach to combating soil degradation and saline water is the cultivation of halophyte plant species ${ }^{48}$. Salinity hinders many metabolic processes in plants and affects crop production ${ }^{20}$. A major adverse impact of salinity is the over-accumulation of $\mathrm{Na}^{+}$and $\mathrm{Cl}^{-}$within cells, which leads to ion imbalance and physiological irregularities. Salinity stress brings about several biochemical, physiological, and morphological changes in plants and affects their growth, photosynthesis, protein synthesis, respiration, and energy production ${ }^{26}$.

Today, researchers are increasingly paying more attention to the use of microorganisms, such as growthpromoting bacteria, to increase yields ${ }^{23}$. Rhizobacters influence plant development and yields and mitigate the risks arising from salt stress in addition to contributing to nitrogen biosynthesis, siderophore production, the dissolution of mineral phosphate, and the production of plant hormones ${ }^{37}$. As such, it is of crucial importance to develop such techniques as the use of biofertilizers that contain bacteria that biologically enhance stress resistance of plants ${ }^{46}$. It was reported that quinoa had a high tolerance to 
salinity in the germination stage, and the application of $\mathrm{N}$ and $\mathrm{P}$ biofertilizers increased its salinity tolerance so that all recorded morphological traits of the quinoa plants treated with biofertilizers were significantly increased compared to the control ${ }^{7}$. It has been found that biofertilizers, in addition to playing a role in the uptake of specific elements, contribute to absorbing other elements, reducing diseases, improving soil structure, further stimulating plant growth, increasing crop quantity and quality, and enhancing plant resistance to environmental stresses including drought and salinity ${ }^{42}$.

Trichoderma is a soil-borne microorganism, some species of which are known to stimulate plant growth $^{32}$. (There is a report as to the increased growth of Trichoderma-treated quinoa plants ${ }^{47}$. Trichoderma protects plants from environmental stresses such as salinity and improves their growth and development ${ }^{12}$. The fungal strains of the genus Trichoderma are known to produce secondary metabolites with different biological activities. Trichoderma can produce fungal materials that are capable of stimulating plants to produce their own defense metabolites ${ }^{62}$. Trichoderma spp. also synthesizes many biologically active compounds, including cell wall-decomposing enzymes ${ }^{63}$.

By establishing and abundantly sporing in the soil environment, especially in the root zone of most crops, Trichoderma species not only reduce pathogens in the soil but also stimulate the growth of plant roots and shoots by biochemical mechanisms ${ }^{31}$. Antioxidants are essential for coping with oxidative stress. A health benefit of quinoa is related to its nutritional properties, as well as the content of biologically active molecules such as phenolic compounds and their antioxidant activity ${ }^{5}$.

This study aimed to investigate the tolerance of quinoa to different salinity levels along with the effect of biofertilizers and Trichoderma on improving morphological parameters, antioxidants, and leaf polyphenolic compounds and to make some practical recommendations for the development of its cultivation in saline regions.

\section{Materials And Methods}

The study was conducted as a factorial experiment based on a completely randomized design with three replications under controlled conditions at the research greenhouse of Agriculture Faculty, Urmia University in 2018. The treatments included salinity at three levels $(0,150$, and $300 \mu \mathrm{M} \mathrm{NaCl})$, Trichoderma at two levels (no fungus and with fungus), and biofertilizer at three levels $(0, N, P)$. The soil was sampled and analyzed before the experiment was initiated (Table 1). Fifty-four 6.5-kg pots containing sterilized soil and sand at a 3:1 ratio were prepared and the soil sample was tested for its composition. Trichoderma was added to each pot at a rate of $7.5 \mathrm{~g}$, and the seeds of quinoa cv. 'Titicaca' were cultivated. The seeds that were supposed to be treated with biofertilizer were impregnated with fertilizer for half an hour. Azotobaror-1 biological fertilizer, which contains the bacteria of Azotobacter vinelandii strain 04 , was used as $\mathrm{N}$ biofertilizer, which actively fixes atmospheric nitrogen in an absorbable form for plants. Barvar-2 phosphate biofertilizer was used as P biofertilizer. It contains two types of phosphate-solubilizing bacteria from the genus Pantoea (strain P5) and Pseudomonas putida (strain P13). After the seeds germinated, six plants were finally kept in each pot. The different rates of salt 
stress were applied to the plants at the one-month (6-leaf) stage, and 10 days later, the plants were harvested. Total phenolic content was determined by Folin-Ciocalteu reagent ${ }^{60}$. The flavonoid content of the extract was estimated by Zhishen et al.'s (1999) ${ }^{71}$ procedure. Also, the HPLC values were determined using a high-performance liquid chromatography device (model series 1100, Agilent, USA) equipped with a 20- $\mu$ injection loop, a four-solvent gradient pump, a degassing system, an oven stone, and a diode array detector, adjusted at 250,272 , and $310 \mathrm{~nm}^{58}$. The data were statistically analyzed using SAS software version 9.4. The means were compared using the PLSD test at the $\mathrm{P}<0.05$ level, and MS-Excel software was used to draw the graphs.

Table 1

The physico-chemical characteristics of the soil at the study site

\begin{tabular}{|c|c|}
\hline Measure parameter & Value \\
\hline Salinity (dS/m) & 0.65 \\
\hline Soil texture & Loam-clay \\
\hline $\mathrm{pH}$ & 6.7 \\
\hline Clay (\%) & 36 \\
\hline Silt (\%) & 55 \\
\hline Sand (\%) & 9 \\
\hline Organic carbon (\%) & 0.20 \\
\hline OM (\%) & 0.34 \\
\hline $\mathrm{CaCO}_{3}(\%)$ & 27.5 \\
\hline$P(\mathrm{mg} / \mathrm{kg})$ & 11 \\
\hline $\mathrm{K}(\mathrm{mg} / \mathrm{kg})$ & 290 \\
\hline
\end{tabular}

\section{Results}

\section{Morphological parameters}

The analysis of data variance showed that the morphological and antioxidant parameters of quinoa were significant at the $\mathrm{P}<0.01$ level (Table 2). 
Table 2

The results of the variance analysis for the effect of salinity, biofertilizer, and Trichoderma on morphological traits and antioxidant of quinoa

\begin{tabular}{|c|c|c|c|c|c|c|c|}
\hline $\begin{array}{l}\text { Sources of } \\
\text { variations }\end{array}$ & df & $\begin{array}{l}\text { Shoot } \\
\text { length } \\
\text { (cm) }\end{array}$ & $\begin{array}{l}\text { Shoot } \\
\text { dry } \\
\text { weight } \\
\text { (g) }\end{array}$ & $\begin{array}{l}\text { Root } \\
\text { Length } \\
\text { (cm) }\end{array}$ & $\begin{array}{l}\text { Root } \\
\text { dry } \\
\text { weight } \\
\text { (g) }\end{array}$ & $\begin{array}{l}\text { Phenols } \\
\text { (mg gallic } \\
\text { acid g DM- } \\
\text { 1) }\end{array}$ & $\begin{array}{l}\text { Flavonoids } \\
\text { (mg gallic } \\
\text { acid g DM- } \\
{ }^{1} \text { ) }\end{array}$ \\
\hline Replication & 2 & $1.185^{\mathrm{ns}}$ & $0.014^{\mathrm{ns}}$ & $1.865^{\mathrm{ns}}$ & $0.003^{\text {ns }}$ & $7.749^{\text {ns }}$ & $0.00001^{\mathrm{ns}}$ \\
\hline A & 2 & $284.129^{\star \star}$ & $1.753^{\star \star}$ & $61.99^{\star \star}$ & $0.067_{\star \star}$ & $1267.38^{\star \star}$ & $0.0041^{\star \star}$ \\
\hline B & 1 & $4.16^{\mathrm{ns}}$ & $0.698^{* *}$ & $0.155^{\mathrm{ns}}$ & $0.006^{\mathrm{ns}}$ & $1615.18^{\star \star}$ & $0.0003^{\star *}$ \\
\hline C & 2 & $364.462^{\star \star}$ & $14.878^{\star \star}$ & $45.48^{\star *}$ & $0.329^{\star *}$ & $572.93^{\star \star}$ & $0.0012^{\star \star}$ \\
\hline$A B$ & 2 & $6.16^{\mathrm{ns}}$ & $3.209^{* \star}$ & $31.28^{\star *}$ & $0.043^{* *}$ & $1374.12^{* *}$ & $0.00004^{\mathrm{ns}}$ \\
\hline$A C$ & 4 & $100.462^{\star \star}$ & $5.889^{\star *}$ & $37.71^{\star *}$ & $0.145^{\star \star}$ & $1625.97^{\star \star}$ & $0.0001^{\star \star}$ \\
\hline $\mathrm{BC}$ & 2 & $92.72^{\star *}$ & $3.587^{\star *}$ & $1.09^{n s}$ & $0.053^{\star *}$ & $3345.46^{\star \star}$ & $0.0002^{\star \star}$ \\
\hline$A B C$ & 4 & $72.38^{\star \star}$ & $4.598^{* *}$ & $178.55^{\star \star}$ & $0.058^{\star \star}$ & $365.43^{\star \star}$ & $0.0004^{\star \star}$ \\
\hline $\begin{array}{l}\text { Experimental } \\
\text { error }\end{array}$ & 34 & 2.518 & 0.083 & 1.76 & 0.002 & 59.52 & 0.00002 \\
\hline $\begin{array}{l}\text { Coefficient of } \\
\text { variation }\end{array}$ & & 3.698 & 8.468 & 6.09 & 11.66 & 11.81 & 7.039 \\
\hline
\end{tabular}

\section{Shoot length}

The highest shoot length $(\mathrm{cm})$ was obtained from the treatment of $S_{0} T_{0} F_{N}$, which was different from the other treatments significantly. The lowest was related to $S_{300} T_{0} F_{p}$, but it did not differ from that of $\mathrm{S}_{300} \mathrm{TF}_{\mathrm{N}}$ and $\mathrm{S}_{300} \mathrm{~T}_{0} \mathrm{C}$ significantly. The plants treated with $\mathrm{P}$ biofertilizer $\left(\mathrm{F}_{\mathrm{P}}\right)$ at the salinity level of $300 \mu \mathrm{M}$ grew longer shoot when they were exposed to Trichoderma than when they were not (Fig. 1).

\section{Shoot dry weight}

The highest shoot dry weight $(\mathrm{g})$ was obtained from the plants treated with $\mathrm{S}_{0} T_{0} F_{N}$, which was different from the other treatments significantly. The lowest one was related to $S_{0} T_{0} C$ and $S_{300} T_{0} C$, but they did not differ from $S_{300} T_{0} F_{N}$ and $S_{150} T_{0} F_{P}$ significantly (Fig. 2).

\section{Root length}


The plants treated with $S_{150} T F_{N}$ grew the longest roots $(\mathrm{cm})$ and differed from the plants exposed to the other treatments significantly. The lowest root length was observed in $S_{300} T F_{N}$. In the salinity levels of 0 and $300 \mu \mathrm{M}$ treated with the biofertilizer $\mathrm{F}_{\mathrm{N}}$ and T, root length was decreased (Fig. 3).

\section{Root dry weight}

The $S_{0} T_{0} F_{N}$-treated plants showed the highest root dry weight $(\mathrm{g})$, differing from the other treatments significantly, and the plants treated with $\mathrm{S}_{0} \mathrm{~T}_{0} \mathrm{~F}_{\mathrm{P}}$ and $\mathrm{S}_{300} \mathrm{TF}_{\mathrm{N}}$ exhibited the lowest one. The plants treated with the biofertilizer $N\left(F_{N}\right)$ at the salinity level of $300 \mu \mathrm{M}\left(S_{300}\right)$ exhibited lower root dry weight when they were exposed to Trichoderma (T) than when they were not (Fig. 4).

\section{Antioxidants}

\section{Phenol}

The highest phenol content (mg gallic acid per $\mathrm{g}$ dry matter) was related to the treatment of $\mathrm{S}_{300} T F_{p}$, but it did not differ from the treatments of $S_{300} T F_{N}, S_{150} T$ C, and $S_{0} T=C$ significantly. The lowest was related to $S_{0} T_{0} F_{N}$ (Fig. 5).

\section{Flavonoid}

The treatment of $\mathrm{S}_{0} \mathrm{TF}_{\mathrm{N}}$ gave rise to the highest flavonoid content (mg gallic acid per g dry matter), not differing from $S_{0} T F_{P}$ significantly. The lowest was obtained from $S_{150} T C$, which was not different from $\mathrm{S}_{300} \mathrm{TC}$ significantly (Fig. 6).

\section{HPLC}

The highest amounts of caffeic acid, rutin, coumaric, and quercetin were related to $S_{0} T F_{p}$ and the highest amounts of chlorogenic, rosmarinic acid, cinnamic acid, and apigenin $(\mathrm{mg} / \mathrm{kg})$ were observed $\operatorname{din} \mathrm{S}_{0} \mathrm{TF}_{\mathrm{N}}$ (Fig. 7).

\section{Discussion}

\section{Morphological traits}

The results show that salinity stress at the rate of $150 \mathrm{mM}$ salt $\left(\mathrm{S}_{150}\right)$ increased quinoa growth, which is the normal halophytic behavior of this plant and is consistent with the report of Parvez et al. $(2020)^{48}$. But, at $300 \mathrm{mM}$ salt $\left(\mathrm{S}_{300}\right)$ treatment, shoot growth was decreased, which is supported by the reports of Becker et al. (2017) $)^{10}$ and Parvez et al. (2020) ${ }^{48}$. The significant reduction in shoot length at high salinity $\left(\mathrm{S}_{300}\right)$ seems to be associated with different responses, including changes in nutrient uptake, cellular 
homeostasis, and metabolic pathways of plants exposed to salinity stress ${ }^{49}$. Osmotic damage, ion toxicity, and changes in the balance of available nutrients are some factors involved in the loss of plant height in saline environments. The decline of plant height under salinity has also been ascribed to physiological dryness of the root zone and competition between the ions of chlorine, sulfate, and nitrate ${ }^{70}$. Salinity stress in the early stages causes osmotic stress, which reduces the water content of cells and inhibits their elongation, and even after osmotic balance and cell turgor are restored, they expand and elongate slowly ${ }^{41}$.

The highest shoot and root length and dry weight were observed in the treatment of $S_{0} T_{0} F_{N}$ at the salinity level of $0 \mathrm{mM}\left(\mathrm{S}_{0}\right)$ and in the treatment of $S_{300} T_{0} F_{N}$ at the salinity level of $300 \mathrm{mM}\left(S_{300}\right)$. The results indicate that at the salinity levels of 0 and $300 \mathrm{mM}$, the $\mathrm{N}$ biofertilizer increased growth when the plants were not treated with Trichoderma $\left(\mathrm{S}_{0} \mathrm{~T}_{0} \mathrm{~F}_{\mathrm{N}}\right)$. The biofertilizer Azotobarvar-1 (containing Azotobacter) is a selective molecular nitrogen fixer that can synthesize and secrete some biologically active substances in the root zone and improve the root system, thereby influencing the uptake of water and nutrients, biological $\mathrm{N}$ fixation, crop yields, and soil properties ${ }^{2}$. Shoot and root length and dry weight were significantly increased by the treatment of $\mathrm{S}_{150} \mathrm{TF}_{\mathrm{N}}$ compared to other treatments at the salinity level of $150 \mathrm{mM}$. In addition to fixing $\mathrm{N}$ and making a balance in nutrient uptake, bacteria of biofertilizers synthesize plant growth promoters and different acids, thereby enhancing root and shoot growth and development, and this, in turn, contributes to more assimilation and its mobilization to other parts ${ }^{7}$.

Trichoderma seems to have an increasing effect on Azotobacter activity at the salinity level of $150 \mathrm{mM}$, which is normal salinity for quinoa as a halophyte plant, but Trichoderma at the salinity levels of $0 \mathrm{mM}$ $\left(\mathrm{S}_{0}\right)$ and $300 \mathrm{mM}\left(\mathrm{S}_{300}\right)$ had an antagonistic effect on Azotobacter activity, which eventually reduced the growth of quinoa. The antagonistic ability of Trichoderma with bacteria has been reported ${ }^{64}$. It has been suggested that the acidification of the buffer by Trichoderma inhibits plant growth ${ }^{50}$. This can affect the interaction of Trichoderma with other organisms and bacteria and even with the plant itself too. At the salinity level of $0 \mathrm{mM}$, the application of $\mathrm{P}$ biofertilizer increased shoot dry weight and root length and decreased root dry weight compared to the control at the same salinity level. The interactive effect of Trichoderma and P biofertilizer was not significant on morphological characteristics at the salinity level of $0 \mathrm{mM}$. In summary, inhibition of plant growth and lack of lateral root growth during simultaneous cultivation of $C$. quinoa with biological control strains of Trichoderma under axenic conditions indicates that Trichoderma, especially growth regimes, can damage plants. The mechanisms of this injury may explain the exceptional cases of increased growth observed in the treated soil-grown crops ${ }^{55}$.

However, at $150 \mathrm{mM}$ salinity, the application of $\mathrm{P}$ biofertilizer reduced shoot length and dry weight and root dry weight and increased root length versus the control at the same salinity level. Biofertilizers have been reported to increase uptake by root through increasing root development ${ }^{69}$. The application of Trichoderma along with $\mathrm{P}$ biofertilizer significantly reduced root length increase, had no significant effect on shoot length, but increased shoot dry weight significantly. It can be inferred from these results that at high salinity $(300 \mathrm{mM})$, the application of Trichoderma along with phosphate-solubilizing bacteria 
influenced plant growth positively, and this effect was significant on length. The phosphate biofertilizer Barvar-2 contains phosphate-solubilizing bacteria that secrete organic acids and acid phosphatase and convert insoluble phosphorus in soil (especially in areas with high soil calcium) into a plant-absorbable form ${ }^{28}$. The interaction of a plant with beneficial microbes varies greatly depending on the genotypes and may range from growth inhibition to growth enhancement and vigorous growth ${ }^{54}$. Different species of Trichoderma are used for their ability to enhance plant growth and development and their ability to grow in adverse conditions ${ }^{66}$. It seems that Trichoderma in the salinity level of $300 \mathrm{mM}$ salt had an increasing effect on the activity of phosphate-solubilizing bacteria and ultimately increased the growth of quinoa in high salinity.

Trichoderma treatment without the presence of bacteria at the salinity level of $150 \mathrm{mM}$ salt $\left(\mathrm{S}_{150} \mathrm{TC}\right)$ decreased root length significantly compared to the control $\left(S_{150} T_{0} C\right)$. Trichoderma had no significant effect on shoot growth and root biomass. At 0 and $300 \mathrm{mM}$ salinity levels, Trichoderma without the presence of bacteria $\left(\mathrm{S}_{300} \mathrm{TC}\right)$ increased shoot length and dry weight significantly compared to the control treatment at the same salinity levels. There are reports as to the increased growth of some plant species, including quinoa, when they were treated with Trichoderma ${ }^{47}$.

By secreting fungal metabolites, activating growth regulating signals and plant growth-responsible phytohormones, and increasing the solubility of soil nutrients, Trichoderma can increase plant growth ${ }^{6,16}$.

\section{Antioxidants}

\section{Total phenol}

At the salinity level of $0 \mathrm{mM}$, the control treatment $\left(\mathrm{S}_{0} \mathrm{~T}_{0} \mathrm{C}\right)$ and at the salinity level of $150 \mathrm{mM}$, the treatment of $S_{150} T_{0} C$ was related to the highest total phenol. This shows that at the salinity level of $0 \mathrm{mM}$, the application of biofertilizers and Trichoderma alone or in combination reduced total phenol content. It seems that the plant spent most of its photosynthates on the growth of plant shoots, which is consistent with the results of this study. Phenolic compounds are secondary plant metabolites that act as substrates for many antioxidant enzymes ${ }^{9}$ or indirectly alleviate the damages of oxidative stress by modulating the function of several proteins associated with this stress ${ }^{30}$. The application of biofertilizers and Trichoderma alone or in combination reduced the amount of total phenol at the salinity level of $150 \mathrm{mM}$ salt. Except for the treatment of $S_{150} T_{0} F_{P}$ in which biomass was significantly reduced, the plants spent most of their photosynthates on shoot growth. In the treatment of $S_{150} T_{0} F_{P}$, the $P$ biofertilizer increased root length, which could be related to the non-selective uptake of elements by carriers and ion channels at low salinity conditions. Decreased pH due to the use of biosulfur biofertilizer can be the reason for the decline of polyphenols in this treatment ${ }^{15}$. In the treatment of $S_{0} T_{0} F_{N}$, total phenol shows the lowest quantity. It can be said that Azotobacter contributed to increasing nitrogen uptake and subsequently increasing protein synthesis and cell growth and proliferation, resulting in a significant increase in shoot and root length and biomass. It seems that an increase in nitrogen uptake is 
the mechanism of the bacteria itself, which has led to no increase in $\mathrm{Na}^{+}$uptake, a reduction of stressful conditions for the cell, and the lack of a need for the increase in total phenol content of the leaves. Total phenol content was increased significantly and remarkably in the treatments of $S_{300} T_{F}$ and $S_{300} T F_{P}$. The treatment of $\mathrm{N}$ or $\mathrm{P}$ biofertilizers with Trichoderma may have increased the uptake of $\mathrm{Na}^{+}$by the roots and its accumulation in the leaves. The absorption of nutrients by cation channels is not selective, and the interaction of Trichoderma and bacteria is likely to increase the activity of $\mathrm{NH}_{4}{ }^{+}$carrier cation channels and subsequently, $\mathrm{Na}^{+}$uptake ${ }^{44}$. Plants exposed to oxidative stress use special defense mechanisms, such as increasing the concentration of total phenol. Studies have shown that different levels of salinity treatment increased total phenol content by $8-35 \%{ }^{4}$. Also, phenol compounds accumulated in the leaves of corn and chickpea to a much greater extent in the plants exposed to salinity stress than those not exposed 29,39 . The use of a combination of seaweed and cyanobacteria as biofertilizer agents improved the growth and phenol content of fava beans ${ }^{52}$. In a study, it was found that an increase in phenol synthesis in Trichoderma-inoculated tomato plants improved their ${ }^{40}$. growth under drought stress, thereby protecting them against oxidative stress by ROS scavenging The increased synthesis of phenols and flavonoids is involved not only in the formation of cell walls, which protects plants against biotic stresses but also in antioxidant activity directly ${ }^{61}$.

The increase in phenolic compounds is due to the fact that free hydroxyl groups attached to the aromatic ring alleviate the oxidative damages caused by ions through scavenging radicals and other mechanisms, e.g. singlet oxygen reduction and metal chelating by bonding to toxic ions, thereby protecting cytoplasm and chloroplast structures against the negative impacts of salinity ${ }^{8}$. It seems that in the treatment of $\mathrm{S}_{300} \mathrm{TF}_{\mathrm{p}}$, proper $\mathrm{Na}^{+}$compartmentation was performed in leaf cells so that the phenols were chelated with $\mathrm{Na}^{+}$and transferred it into the vacuole. By the reduction of cytosolic $\mathrm{Na}^{+}$and the creation of suitable cellular conditions, photosynthetic materials were used to synthesize proteins and materials necessary for growth and increased shoot and root length, as well as shoot and root biomass in this treatment. There are reports as to $\mathrm{Na}^{+}$compartmentation and transfer of cytosolic $\mathrm{Na}^{+}$into the vacuole to prevent the destructive effects of sodium in the cytosol of plant cells ${ }^{24}$. Unlike the treatment of $S_{300} T_{P}$, in the treatment of $\mathrm{N}$ biofertilizer along with Trichoderma at high salinity $\left(\mathrm{S}_{300} \mathrm{TF} \mathrm{F}_{\mathrm{N}}\right)$, there was no increase in shoot and root length and biomass, but root growth was significantly reduced. It seems that most photosynthates are used to synthesize secondary metabolites, the major of which are phenols. The increase in phenol content under osmotic stress in different tissues of many plants can occur due to the role of total phenols in regulating the important mechanism of plant metabolic processes, the overall result of which is the effect on plant growth ${ }^{1}$.

\section{Total flavonoid}

The results showed that flavonoid content did not increase under stress and the production of flavonoids from photosynthates was decreased. Although the application of Trichoderma and biofertilizer alone or in combination reduced the amount of flavonoid reduction in salinity $(150 \mathrm{mM}$ salt), an increase was observed in flavonoid content in all treatments of the $150 \mathrm{mM}$ salinity level versus the control of this 
salinity level. This increase was more significant and pronounced in the treatments of $S_{150} T F_{P}$ and $\mathrm{S}_{150} \mathrm{~T}_{0} \mathrm{~F}_{\mathrm{N}}$. It seems that quinoa's defense system in salinity stress was more based on the increase in other phenols. The highest amount of flavonoids was observed in the treatments of $S_{0} T F_{N}$ and $S_{0} T F_{P}$. Accumulation of phenolic compounds in salinity-tolerant plants is a solution to inhibit the activity of reactive oxygen radicals and protect cell membranes from salinity stress damage ${ }^{59}$. Flavonoid content can be increased by applying biological fertilizers alone or a combination with chemical fertilizers such as nitrogen fertilizers ${ }^{22}$. Factors such as genotype (cultivar), soil, and environment seem to influence biochemical processes that happen during germination versus the primary and secondary metabolites and phenol compounds profile of quinoa ${ }^{14}$. By imposing salinity stress on Chichorium spinosum, researchers observed that it increased flavonoid content and antioxidant activity ${ }^{51}$. Flavonoids are often induced by abiotic stress and are involved in plant protection ${ }^{38}$. Accumulation of flavonoids due to salinity can indicate that the plant needs large amounts of flavonoids to counteract the harmful effects of salinity ${ }^{3}$. Flavonoids make membranes resistant to oxidative agents by reducing fluidity and preventing the release of free radicals ${ }^{38}$. Organic-grown cabbage, spinach, and green peppers generally had higher levels of flavonoid and antioxidant activity ${ }^{19}$. The increased synthesis of flavonoids by Trichoderma-inoculated plants act as endogenous regulators of auxin motions and growth regulator, and these plants may exhibit fine-regulation of growth hormone and photoprotection in photosynthesis pathway ${ }^{13}$.

\section{Polyphenols (HPLC)}

Quinoa leaf is a potentially rich source of phenolic and flavonoid compounds ${ }^{33}$. Gawlik-Dziki et al. $(2013)^{21}$, who analyzed HPLC to identify ChL aglycones of quinoa leaves, detected ten main phenolic acids and four flavonoids in the chemical polyphenolic fraction. The main phenolic acids included ferulic, sinapinic, and gallic acids, whereas kaempferol and isoramentine were the most abundant flavonoid. Also, a great deal of rutin was observed. Quercetin has been reported in the shoot of $C$. album ${ }^{36}$. Among the phenolic compounds studied in this research, rosemaric and coumaric acids were the predominant phenolic compounds in quinoa leaves. Caffeic acid was observed in lower amounts. The amounts of cinnamic and chlorogenic acids were slight, all of which showed a significant increase in the treatments of $\mathrm{S}_{0} \mathrm{TF}_{\mathrm{N}}$ and $\mathrm{S}_{0} \mathrm{TF}_{\mathrm{p}}$. Apigenin was present in small amounts in all treatments but showed a large increase in the treatments of $S_{0} T F_{N}$ and $S_{0} T F_{P}$. Rutin was found in almost the same amount and quercetin in different amounts in all treatments, but the amount of these two flavonoids was also increased significantly in the treatments of $S_{0} T_{F}$ and $S_{0} T F_{P}$. Apigenin content was also increased slightly in these two treatments. On the other hand, total flavonoid content was remarkably enhanced in these two treatments. The results are consistent with one another. The stressful conditions along with $F_{P}$ and $F_{N}$ and Trichoderma were effective in increasing total phenol. The results seem to depend upon not only the plant's response to different levels of salt but also the interaction among antioxidants. Phenolic compounds can influence one another antagonistically. These changes in the amount of the studied phenols can indicate the different antioxidant potential of various compounds in dealing with salinity 
stress and the interaction between microorganisms. Phenolic compounds encompass a wide range of compounds, including phenolic acids, flavonoids, and tannins ${ }^{35}$. The increase in total phenol in the treatments of $S_{300} T F_{N}$ and $S_{300} T F_{P}$ could be related to other phenolic compounds that have not been studied and measured in this study. In plants, the biological synthesis of polyphenols and their accumulation is generally stimulated in response to biotic/abiotic stress such as salinity. Plants exposed to salinity stress may provide potential sources of polyphenols by increasing the concentration of polyphenols in their tissues and limiting biomass production. The optimal performance of polyphenols has been suggested to be accomplished by using stress-tolerant species ${ }^{53}$. An increased level of phenolic acids has been reported with increasing $\mathrm{NaCl}$ concentrations in barley ${ }^{57}$. El-Din et al. (2009) ${ }^{18}$ reported that salinity stress exposure of thyme increased such compounds as caffeic, chlorogenic, ferulic, and rosemaric acids. In M. chamomilla, the accumulation of phenolic acids such as chlorogenic and caffeic acids was increased with increasing salinity ${ }^{34}$. In Nigella sativa, salinity stress increased the biosynthesis of some specific phenolic compounds such as quercetin, apigenin, and trans-cinnamic acid ${ }^{11}$. There is another report that salinity stress can cause the accumulation of phenolic compounds in plant tissues ${ }^{68}$. A study on artichoke revealed that the amount of polyphenolic compounds was decreased with increasing salinity 27 . The results on olives showed that the use of Trichoderma increased the concentration of polyphenols in olive leaves ${ }^{17}$.

\section{Conclusions}

The present study investigated the effect of salinity stress, bacteria biofertilizers, and Trichoderma on morphological traits, antioxidants, and polyphenol compounds of quinoa. The results showed that the application of biofertilizers and Trichoderma under salinity stress influenced morphological traits, antioxidants, and polyphenol compounds of this plant species. At the salinity level of $300 \mathrm{mM}$, the application of Trichoderma had an increasing impact on the activity of phosphate solubilizing bacteria and finally induced resistance and increased the growth of the quinoa plants under severe salinity levels. The results revealed that at severe salinity levels, biofertilizers along with Trichoderma were effective in improving total phenols. Flavonoid content was not increased in stressful conditions, and the defensive system of this plant in salinity stress is more based on increasing other phenols. In total, it is recommended to apply bacterial biofertilizers along with Trichoderma to increase quantitative and qualitative traits of quinoa.

\section{References}

1. Abd Allah, M. M. S., El-Bassiouny, H. M. S., Bakry, B. A., \& Sadak, M. S. Effect of arbuscular mycorrhiza and glutamic acid on growth, yield, some chemical composition and nutritional quality of wheat plant grown in newly reclaimed sandy soil. J. Pharmac. Biolo. Chem. Sci. 6(3), 1038-1054. 2015)). 
2. Akbari, P., Ghalavand, A., \& Modarres Sanavi, S. Effect of different nutritional regimes (organic, chemical, integrated) and biofertilizers on seed yield and other agronomic traits of sunflowers. Sust. Agric. Knowl. 1 (1), 83-93. (2010).

3. Akhavan Hezaveh, T., Pourakbar, L., Rahmani, F., \& Alipour, H. Effects of ZnO NPs on phenolic compounds of rapeseed seeds under salinity stress. Plant. Pro. Func. 8(34), 11-18.2020) ).

4. Alam, M. A., Juraimi, A. S., Rafii, M. Y., Hamid, A. A., Aslani, F., \& Alam, M. Z. Effects of salinity and salinity-induced augmented bioactive compounds in purslane (Portulaca oleracea) for possible economical use. Food. Chem. 169, 439-447.2015) ).

5. Aloisi, I., Parrotta, L., Ruiz, K. B., Landi, C., Bini, L., Cai, G., \& Del Duca, S. New insight into quinoa seed quality under salinity: changes in proteomic and amino acid profiles, phenolic content, and antioxidant activity of protein extracts. Plant. Sci. 7, 656.2016)).

6. Altomare, C., Norvell, W. A., Björkman, T., \& Harman, G. E. Solubilization of phosphates and micronutrients by the plant-growth-promoting and biocontrol fungus Trichoderma harzianum Rifai 1295-22. Env. Micro. 65(7), 2926-2933.1999) ).

7. Amiryousefi, M., Tadayon, M. R., \& Hoseinifard, M. S. Effect of Nitrogen and Phosphorus Bio Fertilizers on Some Seed Germination Traits of Two Cultivars of Quinoa under Salinity Stress. Eco. Eng. J.8(24), 79-94.2019) ).

8. Apel, K., \& Hirt, H. Reactive oxygen species: metabolism, oxidative stress, and signal transduction. Rev. Plant. Biol.55, 373-399. (2004).

9. Bakry, B. A., El-Hariri, D. M., Sadak, M. S., \& El-Bassiouny, H. M. S. Drought stress mitigation by foliar application of salicylic acid in two linseed varieties grown under newly reclaimed sandy soil. Appl. Sci. Res. 8(7), 3503-3514.2012) ).

10. Becker, V. I., Goessling, J. W., Duarte, B., Caçador, I., Liu, F., Rosenqvist, E., \& Jacobsen, S. E. Combined effects of soil salinity and high temperature on photosynthesis and growth of quinoa plants (Chenopodium quinoa). Plant. Biol. 44(7), 665-678.2017) ).

11. Bourgou, S., Kchouk, M. E., Bellila, A., \& Marzouk, B. Effect of salinity on phenolic composition and biological activity of Nigella sativa. Sym. Med. Aro. Plants. 853 (pp. 57-60).2009) ).

12. Brotman, Y., Landau, U., Cuadros-Inostroza, Á., Takayuki, T., Fernie, A. R., Chet, I., \& Willmitzer, L. Trichoderma-plant root colonization: escaping early plant defense responses and activation of the antioxidant machinery for saline stress tolerance. Pathog, 9(3), e1003221.2013) ).

13. Brunetti, C., Di Ferdinando, M., Fini, A., Pollastri, S., \& Tattini, M. Flavonoids as antioxidants and developmental regulators: relative significance in plants and humans. J. Mol. Sci. 14(2), 3540-3555. 2013)).

14. Carciochi, R. A., Manrique, G. D., \& Dimitrov, K. Changes in phenolic composition and antioxidant activity during germination of quinoa seeds (Chenopodium quinoa Willd.).2014)).

15. Chen, J. H. The combined use of chemical and organic fertilizers and/or biofertilizer for crop growth and soil fertility. workshop. Sust. Mana. Soil. Rhizo. Sys. Effic. Crop. Pro. Fert. Use.(Vol. 16, No. 20), (pp. 1-11). Land Development Department Bangkok Thailand.2006) ). 
16. Contreras-Cornejo, H. A., Macías-Rodríguez, L., del-Val, E., \& Larsen, J. Ecological functions of Trichoderma spp. and their secondary metabolites in the rhizosphere: interactions with plants. Micro. Eco.92(4), fiw036.2016) ).

17. Dini, I., Graziani, G., Fedele, F. L., Sicari, A., Vinale, F., Castaldo, L., \& Ritieni, A. Effects of Trichoderma biostimulation on the phenolic profile of extra-virgin olive oil and olive oil by-products. 9(4), 284. 2020)).

18. El-Din, A. E., Aziz, E. E., Hendawy, S. F., \& Omer, E. A. Response of Thymus vulgaris L. to salt stress and alar (B9) in newly reclaimed soil. Appl. Sci. Res. 5(12), 2165-2170.2009)).

19. Farfour, S. A., Al-Saman, M. A., \& Hamouda, R. A. Potential activity of some biofertilizer agents on antioxidant and phytochemical constituents of faba bean plant. Adv. Res. J. Agr. Sci. 4, 26-32. 2015)).

20. Flowers, T. J., \& Colmer, T. D. Plant salt tolerance: adaptations in halophytes. Bot. 115(3), 327-331. 2015)).

21. Gawlik-Dziki, U., Świeca, M., Sułkowski, M., Dziki, D., Baraniak, B., \& Czyż, J. Antioxidant and anticancer activities of Chenopodium quinoa leaves extracts-in vitro study. Chem. Toxico. 57, 154160.2013) ).

22. Gendy, A. S., Said-Al Ahl, H. A., Mahmoud, A. A., \& Mohamed, H. F. Effect of nitrogen sources, biofertilizers and their interaction on the growth, seed yield and chemical composition of guar plants. Sci. J. 10(3), 389-402.2013) ).

23. Gholami, A., Shahsavani, S., \& Nezarat, S. wheat yield under inoculation of arbuscular The Effect of Plant Growth Promoting Rhizobacteria mycorrhiza fungi and Azotobacter chroococcum.(PGPR) on Germination, Seedling Growth and Yield of Haryana Agricultural University. Hisar, India. Plant Maize. Aca. Sci. Eng. Soil. Env.50 (9), 409-415. Techno. 49, 19-24.2009) ).

24. Gouiaa, S., Khoudi, H., Leidi, E. O., Pardo, J. M., \& Masmoudi, K. Expression of wheat $\mathrm{Na}+/ \mathrm{H}+$ antiporter TNHXS1 and H+-pyrophosphatase TVP1 genes in tobacco from a bicistronic transcriptional unit improves salt tolerance. Molec. Biol. 79(1-2), 137-155.2012) ).

25. Gunes, A., Inal, A., Alpaslan, M., Eraslan, F., Bagci, E. G., \& Cicek, N. Salicylic acid induced changes on some physiological parameters symptomatic for oxidative stress and mineral nutrition in maize (Zea mays) grown under salinity. J. Plant. Physiol. 164(6), 728-736.2007) ).

26. Gupta, B., \& Huang, B. Mechanism of salinity tolerance in plants: physiological, biochemical, and molecular characterization. J. Gen. (2014).

27. Hanen, F., Ksouri, R., Megdiche, W., Trabelsi, N., Boulaaba, M., \& Abdelly, C. Effect of salinity on growth, leaf-phenolic content and antioxidant scavenging activity in Cynara cardunculusBios. Agric. High. Sali. Tole. (pp. 335-343). (2008). Birkhäuser Basel.

28. Hazarika, D. K., Talukdar, N. C., Phookan, A. K., Saikia, U. N., Das, B. C., \& Deka, P. C. Influence of vesicular arbascular mycorrhizal fungi and phosphate solubilizing bacteria on nursery establishment and growth of tea seeding in Assam. In Wor. Cong. Soil. Sci. Ban. (Thai), 14-21. (2002). 
29. Hichem, H., \& Mounir, D. Differential responses of two maize (Zea mays) varieties to salt stress: changes on polyphenols composition of foliage and oxidative damages. Ind. Crops. Pro. 30(1), 144151.2009)).

30. Hirose, Y., Fujita, T., Ishii, T., \& Ueno, N. Antioxidative properties and flavonoid composition of Chenopodium quinoa seeds cultivated in Japan. Chem. 119(4), 1300-1306.2010) ).

31. Jancurová, M., Minarovičová, L., \& Dandar, A. Quinoa-a rewiev. J. Food. Sci. 27(2), 71-79.2009) ).

32. Kleifeld, O., \& Chet, I. Trichoderma harzianum-interaction with plants and effect on growth response. Soil. 144(2), 267-272.1992)).

33. Kokanova-Nedialkova, Z., Nedialkov, P. T., \& Nikolov, S. D. The genus Chenopodium: phytochemistry, ethnopharmacology and pharmacology. Rev.3(6), 280.2009)).

34. Kováčik, J., Klejdus, B., Hedbavny, J., \& Bačkor, M. Salicylic acid alleviates NaCl-induced changes in the metabolism of Matricaria chamomilla plants. (5), 544-554.2009) ).

35. Kumaran, A., \& Karunakaran, R. J. In vitro antioxidant activities of methanol extracts of five Phyllanthus species from India. Food. Sci. Tech. 40(2), 344-352.2007) ).

36. Laghari, A. H., Memon, S., Nelofar, A., Khan, K. M., \& Yasmin, A. Determination of free phenolic acids and antioxidant activity of methanolic extracts obtained from fruits and leaves of Chenopodium album. Chem. 126(4), 1850-1855.2011) ).

37. Matiacevich, S. B., Castellión, M. L., Maldonado, S. B., \& Buera, M. P. Water-dependent thermal transitions in quinoa embryos. Acta, 448(2), 117-122.2006)).

38. Mierziak, J., Kostyn, K., \& Kulma, A. Flavonoids as important molecules of plant interactions with the environment. 19(10), 16240-16265.2014)).

39. Miljus-Djukic, J., Stanisavljevic, N., Radovic, S., Jovanovic, Z., Mikic, A., \& Maksimovic, V. Differential response of three contrasting pea ('Pisum arvense, P. sativum'and P.'fulvum') species to salt stress: Assessment of variation in antioxidative defence and miRNA expression. J. Crop. Sci. 7(13), 2145. 2013)).

40. Mona, S. A., Hashem, A., Abd_Allah, E. F., Alqarawi, A. A., Soliman, D. W. K., Wirth, S., \& Egamberdieva, D. Increased resistance of drought by Trichoderma harzianum fungal treatment correlates with increased secondary metabolites and proline content. Int. Agric. 16(8), 1751-1757.2017) ).

41. Munns, R., \& Tester, M. Mechanisms of salinity tolerance. Rev. Plant. Biol., 59, 651-681.2008)).

42. Nagananda, G. S., Das, A., Bhattacharya, S., \& Kalpana, T. In vitro Studies on the Effects of Biofertilizers(Azotobacter and Rhizobium) on Seed Germination and Development of Trigonella foenum-graecum using a Novel Glass Marble containing Liquid Medium. Int. J. Bot. 6(4), 394-403. 2010)).

43. Negrão, S., Schmöckel, S. M., \& Tester, M. Evaluating physiological responses of plants to salinity stress. Bot.119(1), 1-11.2017)).

44. Niu, Y. F., Chai, R. S., Jin, G. L., Wang, H., Tang, C. X., \& Zhang, Y. S. Responses of root architecture development to low phosphorus availability: a review. Bot.112(2), 391-408.2013)). 
45. Oelke, E. A., Oplinger, E. S., Teynor, T. M., Putnam, D. H., Doll, J. D., Kelling, K. A., \& Noetzel, D. M. Safflower. Field. Crops. Man.1992)).

46. Ortuño, N., Castillo, J. A., Claros, M., Navia, O., Angulo, M., Barja, D., \& Angulo, V. Enhancing the sustainability of quinoa production and soil resilience by using bioproducts made with native microorganisms. 3(4), 732-746.2013)).

47. Ortuño, N., Castillo, J. A., Miranda, C., Claros, M., \& Soto, X. The use of secondary metabolites extracted from Trichoderma for plant growth promotion in the Andean highlands. Agric. Food. Sys. 32(4), 366-375.2017))

48. Parvez, S., Abbas, G., Shahid, M., Amjad, M., Hussain, M., Asad, S. A., \& Naeem, M. A. Effect of salinity on physiological, biochemical and photostabilizing attributes of two genotypes of quinoa (Chenopodium quinoa Willd.) exposed to arsenic stress. Env. Saf. 187, 109814.2020)).

49. Patterson, J. H., Newbigin, E. D., Tester, M., Bacic, A., \& Roessner, U. Metabolic responses to salt stress of barley (Hordeum vulgare) cultivars, Sahara and Clipper, which differ in salinity tolerance. J. Exp. Bot. 60(14), 4089-4103.2009)).

50. Pelagio-Flores, R., Esparza-Reynoso, S., Garnica-Vergara, A., López-Bucio, J., \& Herrera-Estrella, A. Trichoderma-induced acidification is an early trigger for changes in Arabidopsis root growth and determines fungal phytostimulation. Plant. Sci.8, 822.2017)).

51. Petropoulos, S. A., Levizou, E., Ntatsi, G., Fernandes, Â., Petrotos, K., Akoumianakis, K., \& Ferreira, I. C. Salinity effect on nutritional value, chemical composition and bioactive compounds content of Cichorium spinosumFood. Chem. 214, 129-136.2017)) .

52. Ragaa, A. H., \& Safinaz, A. F. Enhancement the growth and phenolic content of faba bean (Vicia faba) by applying some biofertilizer agents. J. Food. Stu. 2(2), 20-30.2013)).

53. Rebey, I. B., Bourgou, S., Rahali, F. Z., Msaada, K., Ksouri, R., \& Marzouk, B. Relation between salt tolerance and biochemical changes in cumin (Cuminum cyminum) seeds. J. Food. Drug. Anal.25(2), 391-402.2017)) ).

54. Rollano Penaloza, O. M. Molecular interactions between quinoa, the biocontrol agent Trichoderma and the pathogen Peronospora variabilis(Doctoral dissertation, Lund University).2019) ).

55. Rollano-Peñaloza, O. M., Widell, S., Mollinedo, P., \& Rasmusson, A. G. Trichoderma harzianum T-22 and BOL-12QD inhibit lateral root development of Chenopodium quinoa in axenic co-culture. Biol. 4(1), 1530493.2018)).

56. Sairam, R. K., Rao, K. V., \& Srivastava, G. C. Differential response of wheat genotypes to long term salinity stress in relation to oxidative stress, antioxidant activity and osmolyte concentration. Sci.163(5), 1037-1046.2002)).

57. Sarker, U., \& Oba, S. Augmentation of leaf color parameters, pigments, vitamins, phenolic acids, flavonoids and antioxidant activity in selected Amaranthus tricolor under s alinity stress. Rep. 8(1), 1-9.2018)).

58. Seal, T. Quantitative HPLC analysis of phenolic acids, flavonoids and ascorbic acid in four different solvent extracts of two wild edible leaves, Sonchus arvensis and Oenanthe linearis of North-Eastern 
region in India. Appl. Pharma. Sci. 6(2), 157-166.2016) ).

59. Singh, A. K. The physiology of salt tolerance in four genotypes of chickpea during germination. 2018)).

60. Slinkard, K., \& Singleton, V. L. Total phenol analysis: automation and comparison with manual methods. J. Enol. Viticu. 28(1), 49-55.1977) ).

61. Surekha, C. H., Neelapu, N. R. R., Prasad, B. S., \& Ganesh, P. S. Induction of defense enzymes and phenolic content by Trichoderma viride in Vigna mungo infested with Fusarium oxysporum and Alternaria alternata. J. Agric. Sci. Res. 4(4), 31-40.2014)).

62. Vinale, F., Sivasithamparam, K., Ghisalberti, E. L., Ruocco, M., Woo, S., \& Lorito, M. Trichoderma secondary metabolites that affect plant metabolism. Pro. Comm., 7(11), 1934578X1200701133. 2012)).

63. Vinale, F., Sivasithamparam, K., Ghisalberti, E. L., Marra, R., Woo, S. L., \& Lorito, M. Trichodermaplant-pathogen interactions. Biology. Biochem. 40(1), 1-10.2008)).

64. Vos, C. M., De Cremer, K., Cammue, B. P., \& De Coninck, B. The toolbox of T richoderma spp. in the biocontrol of B otrytis cinerea disease. Plant. Patho. 16(4), 400-412.2015) ).

65. Wang, J., Cao, X., Jiang, H., Qi, Y., Chin, K. L., \& Yue, Y. Antioxidant activity of leaf extracts from different Hibiscus sabdariffa accessions and simultaneous determination five major antioxidant compounds by LC-Q-TOF-MS. 19(12), 21226-21238.2014) ).

66. Waghunde, R. R., Shelake, R. M., \& Sabalpara, A. N. Trichoderma: A significant fungus for agriculture and environment. J. Agric. Res. 11(22), 1952-1965.2016) ).

67. Wright, K. H., Pike, O. A., Fairbanks, D. J., \& Huber, C. S. Composition of Atriplex hortensis, sweet and bitter Chenopodium quinoa seeds. Food. Sci.67(4), 1383-1385.2002) ).

68. Yan, K., Cui, M., Zhao, S., Chen, X., \& Tang, X. Salinity stress is beneficial to the accumulation of chlorogenic acids in honeysuckle (Lonicera japonica Thunb.). Plant. Sci. 7, 1563.2016) ).

69. Yosefi, K., Galavi, M., Ramrodi, M., \& Mousavi, S. R. Effect of bio-phosphate and chemical phosphorus fertilizer accompanied with micronutrient foliar application on growth, yield and yield components of maize (Single Cross 704). J. Crop. Sci. 5(2), 175. (2011).

70. Zamani, S., Nezami, M. T., HABIBI, D., \& Baybordi, A. Study of yield and yield components of winter rapeseed under salt stress conditions.2010)).

71. Zhishen, J., Mengcheng, T., \& Jianming, W. The determination of flavonoid contents in mulberry and their scavenging effects on superoxide radicals. Chem. 64(4), 555-559.1999)).

\section{Figures}




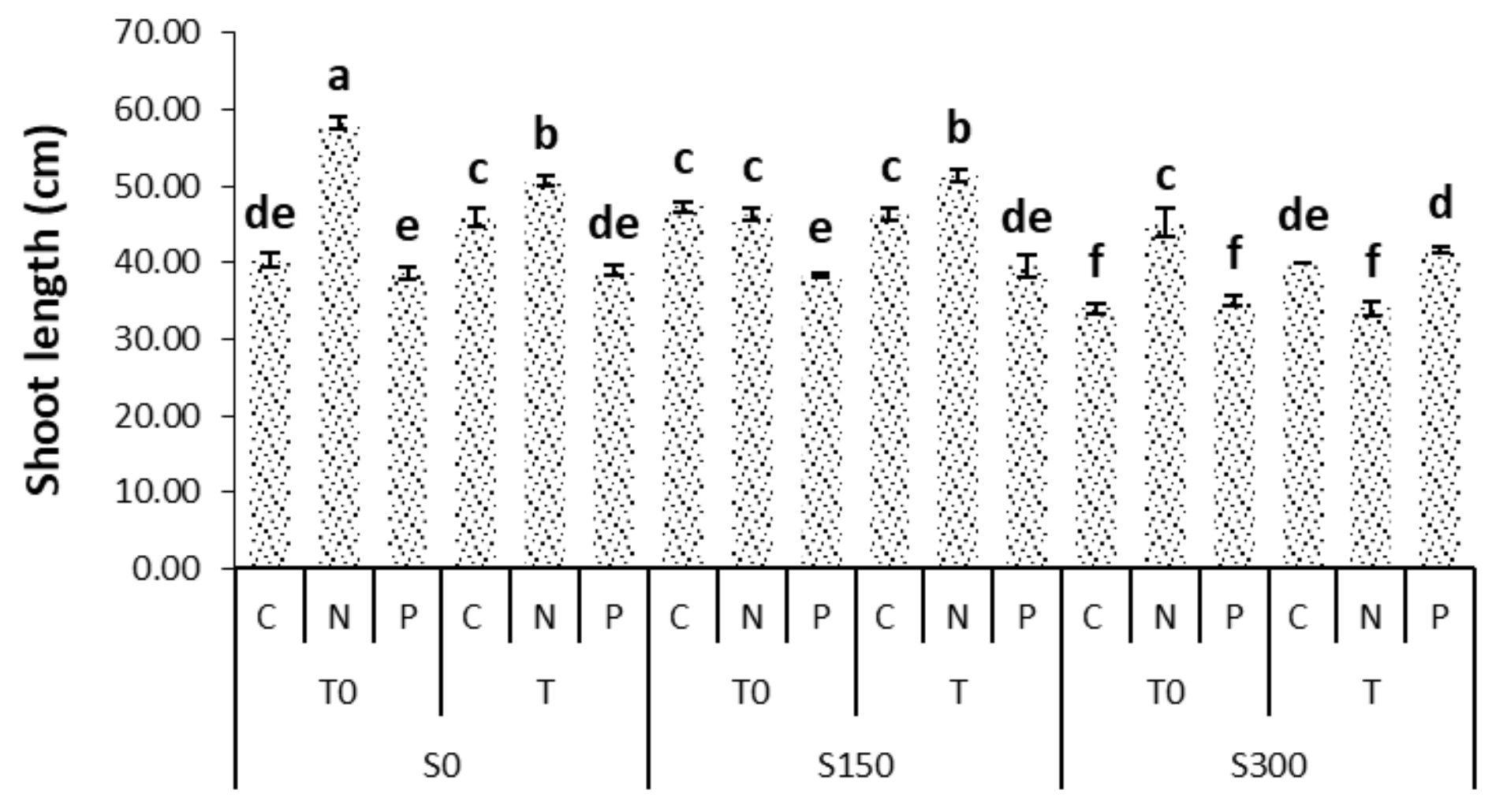

Treatments

Figure 1

Means comparison for the shoot length of quinoa affected by salinity stress, biofertilizers, and Trichoderma. Unsimilar letters show significant difference at the $P<0.01$ level. (SOTOC: no salinity $\times$ no Trichoderma $\times$ no biofertilizer; SOTOFN: no salinity $\times$ no Trichoderma $\times$ N biofertilizer; SOTOFP: no salinity $\times$ no Trichoderma $\times$ P biofertilizer; SOTC: no salinity $\times$ Trichoderma $\times$ no biofertilizer; SOTFN: no salinity $\times$ Trichoderma $\times \mathrm{N}$ biofertilizer; SOTFN: no salinity $\times$ Trichoderma $\times$ P biofertilizer; S150TOC: $150 \mathrm{mM}$ salinity $\times$ no Trichoderma $\times$ no biofertilizer; S150T0FN: $150 \mathrm{mM}$ salinity $\times$ no Trichoderma $\times \mathrm{N}$ biofertilizer; S150T0FP: $150 \mathrm{mM}$ salinity $\times$ no Trichoderma $\times$ P biofertilizer; S150TC: $150 \mathrm{mM}$ salinity $\times$ Trichoderma $\times$ no biofertilizer; S150TFN: $150 \mathrm{mM}$ salinity $\times$ Trichoderma $\times \mathrm{N}$ biofertilizer; S150TFP: 150 $\mathrm{mM}$ salinity $\times$ Trichoderma $\times$ P biofertilizer; S300TOC: $300 \mathrm{mM}$ salinity $\times$ no Trichoderma $\times$ no biofertilizer; S300TOFN: $300 \mathrm{mM}$ salinity $\times$ no Trichoderma $\times$ N biofertilizer; S300T0FP: $300 \mathrm{mM}$ salinity $\times$ no Trichoderma $\times$ P biofertilizer; S300TC: $300 \mathrm{mM}$ salinity $\times$ Trichoderma $\times$ no biofertilizer; S300TFN: 300 $\mathrm{mM}$ salinity $\times$ Trichoderma $\times \mathrm{N}$ biofertilizer; S300TFP: $300 \mathrm{mM}$ salinity $\times$ Trichoderma $\times \mathrm{P}$ biofertilizer) . 


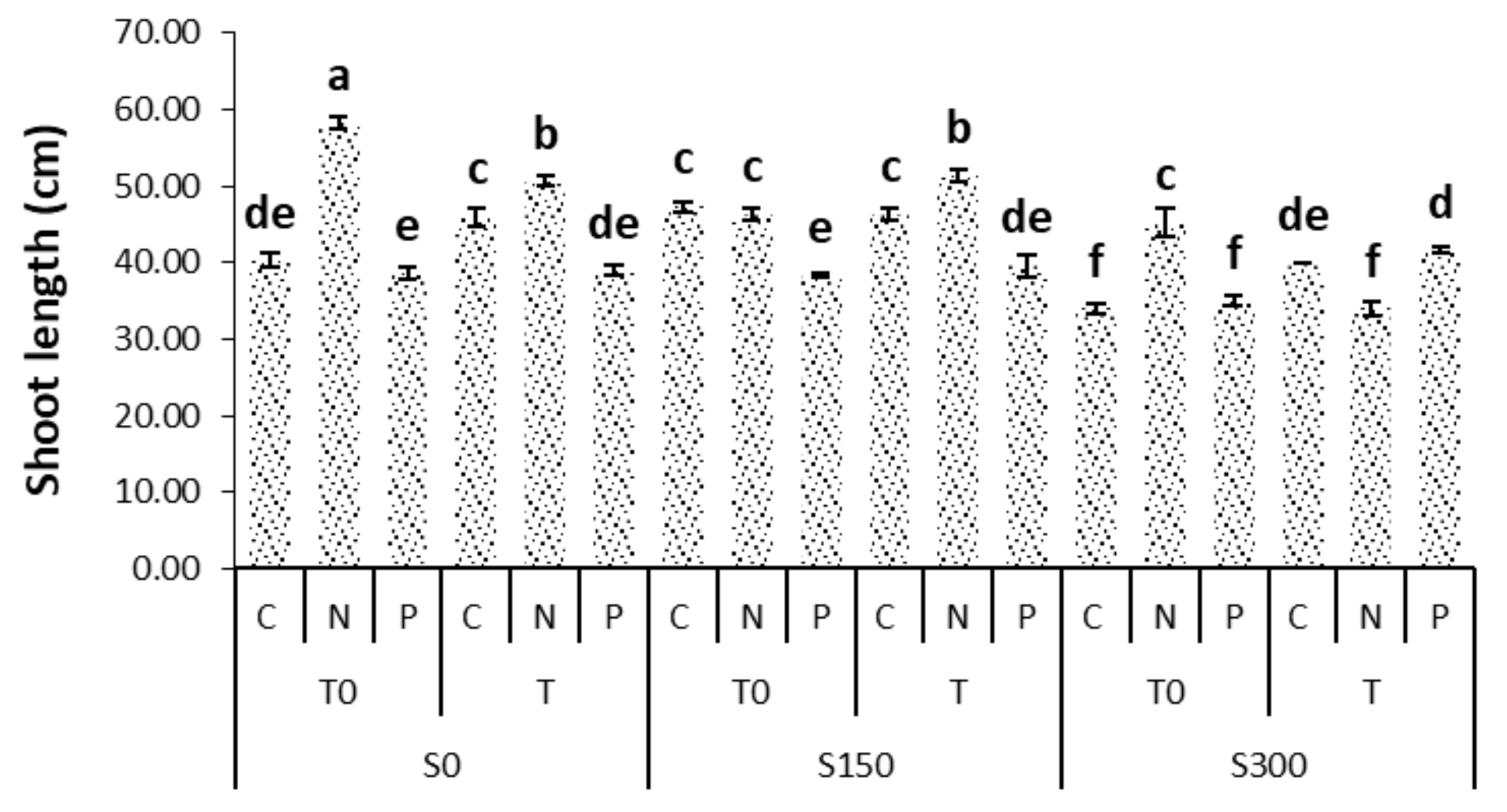

Treatments

Figure 1

Means comparison for the shoot length of quinoa affected by salinity stress, biofertilizers, and Trichoderma. Unsimilar letters show significant difference at the $P<0.01$ level. (SOTOC: no salinity $\times$ no Trichoderma $\times$ no biofertilizer; SOTOFN: no salinity $\times$ no Trichoderma $\times$ N biofertilizer; SOTOFP: no salinity $\times$ no Trichoderma $\times$ P biofertilizer; SOTC: no salinity $\times$ Trichoderma $\times$ no biofertilizer; SOTFN: no salinity $\times$ Trichoderma $\times \mathrm{N}$ biofertilizer; SOTFN: no salinity $\times$ Trichoderma $\times$ P biofertilizer; S150TOC: $150 \mathrm{mM}$ salinity $\times$ no Trichoderma $\times$ no biofertilizer; S150T0FN: $150 \mathrm{mM}$ salinity $\times$ no Trichoderma $\times \mathrm{N}$ biofertilizer; S150T0FP: $150 \mathrm{mM}$ salinity $\times$ no Trichoderma $\times$ P biofertilizer; S150TC: $150 \mathrm{mM}$ salinity $\times$ Trichoderma $\times$ no biofertilizer; S150TFN: $150 \mathrm{mM}$ salinity $\times$ Trichoderma $\times \mathrm{N}$ biofertilizer; S150TFP: 150 $\mathrm{mM}$ salinity $\times$ Trichoderma $\times$ P biofertilizer; S300TOC: $300 \mathrm{mM}$ salinity $\times$ no Trichoderma $\times$ no biofertilizer; S300TOFN: $300 \mathrm{mM}$ salinity $\times$ no Trichoderma $\times$ N biofertilizer; S300T0FP: $300 \mathrm{mM}$ salinity $\times$ no Trichoderma $\times$ P biofertilizer; S300TC: $300 \mathrm{mM}$ salinity $\times$ Trichoderma $\times$ no biofertilizer; S300TFN: 300 $\mathrm{mM}$ salinity $\times$ Trichoderma $\times \mathrm{N}$ biofertilizer; S300TFP: $300 \mathrm{mM}$ salinity $\times$ Trichoderma $\times \mathrm{P}$ biofertilizer) . 


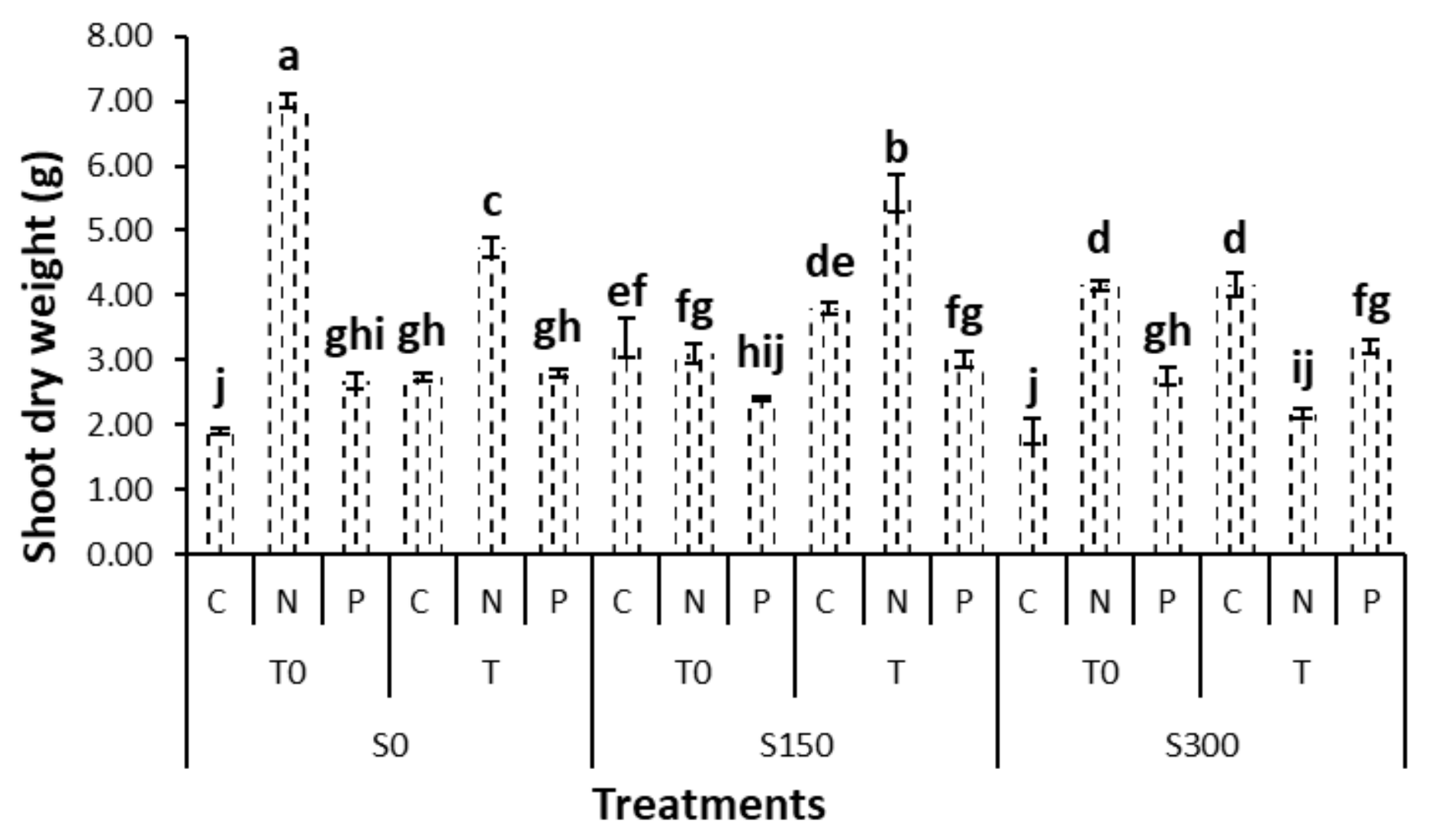

Figure 2

Means comparison for the shoot dry weight of quinoa affected by salinity stress, biofertilizers, and Trichoderma. Unsimilar letters show significant difference at the $P<0.01$ level. (SOTOC: no salinity $\times$ no Trichoderma $\times$ no biofertilizer; SOTOFN: no salinity $\times$ no Trichoderma $\times$ N biofertilizer; SOTOFP: no salinity $\times$ no Trichoderma $\times$ P biofertilizer; SOTC: no salinity $\times$ Trichoderma $\times$ no biofertilizer; SOTFN: no salinity $\times$ Trichoderma $\times \mathrm{N}$ biofertilizer; S0TFN: no salinity $\times$ Trichoderma $\times$ P biofertilizer; S150TOC: $150 \mathrm{mM}$ salinity $\times$ no Trichoderma $\times$ no biofertilizer; S150T0FN: $150 \mathrm{mM}$ salinity $\times$ no Trichoderma $\times \mathrm{N}$ biofertilizer; S150TOFP: $150 \mathrm{mM}$ salinity $\times$ no Trichoderma $\times$ P biofertilizer; S150TC: $150 \mathrm{mM}$ salinity $\times$ Trichoderma $\times$ no biofertilizer; S150TFN: $150 \mathrm{mM}$ salinity $\times$ Trichoderma $\times \mathrm{N}$ biofertilizer; S150TFP: 150 $\mathrm{mM}$ salinity $\times$ Trichoderma $\times$ P biofertilizer; S300TOC: $300 \mathrm{mM}$ salinity $\times$ no Trichoderma $\times$ no biofertilizer; S300TOFN: $300 \mathrm{mM}$ salinity $\times$ no Trichoderma $\times$ N biofertilizer; S300TOFP: $300 \mathrm{mM}$ salinity $\times$ no Trichoderma $\times$ P biofertilizer; S300TC: $300 \mathrm{mM}$ salinity $\times$ Trichoderma $\times$ no biofertilizer; S300TFN: 300 $\mathrm{mM}$ salinity $\times$ Trichoderma $\times \mathrm{N}$ biofertilizer; S300TFP: $300 \mathrm{mM}$ salinity $\times$ Trichoderma $\times \mathrm{P}$ biofertilizer) . 


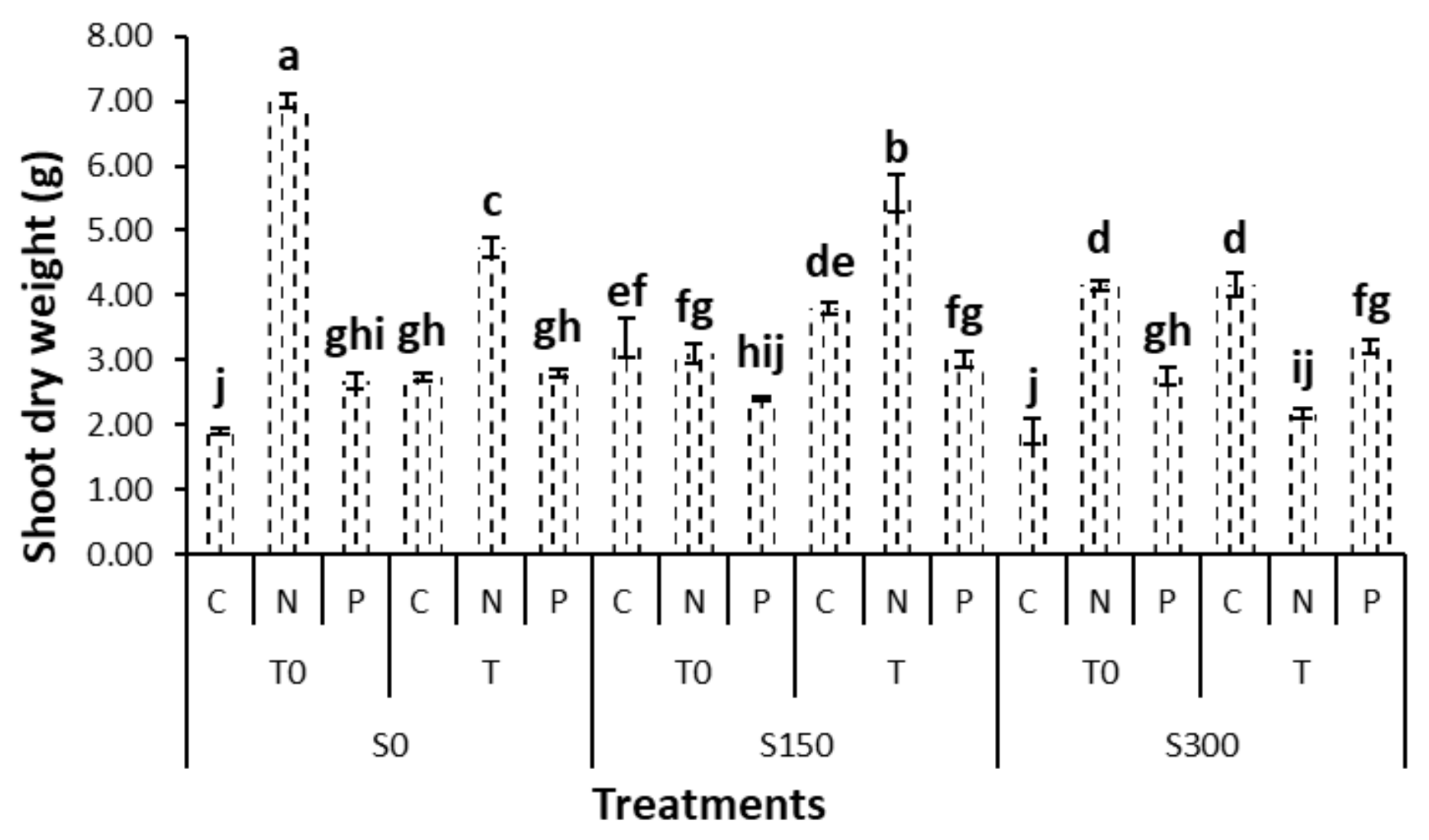

Figure 2

Means comparison for the shoot dry weight of quinoa affected by salinity stress, biofertilizers, and Trichoderma. Unsimilar letters show significant difference at the $P<0.01$ level. (SOTOC: no salinity $\times$ no Trichoderma $\times$ no biofertilizer; SOTOFN: no salinity $\times$ no Trichoderma $\times$ N biofertilizer; SOTOFP: no salinity $\times$ no Trichoderma $\times$ P biofertilizer; SOTC: no salinity $\times$ Trichoderma $\times$ no biofertilizer; SOTFN: no salinity $\times$ Trichoderma $\times \mathrm{N}$ biofertilizer; S0TFN: no salinity $\times$ Trichoderma $\times$ P biofertilizer; S150TOC: $150 \mathrm{mM}$ salinity $\times$ no Trichoderma $\times$ no biofertilizer; S150T0FN: $150 \mathrm{mM}$ salinity $\times$ no Trichoderma $\times \mathrm{N}$ biofertilizer; S150TOFP: $150 \mathrm{mM}$ salinity $\times$ no Trichoderma $\times$ P biofertilizer; S150TC: $150 \mathrm{mM}$ salinity $\times$ Trichoderma $\times$ no biofertilizer; S150TFN: $150 \mathrm{mM}$ salinity $\times$ Trichoderma $\times \mathrm{N}$ biofertilizer; S150TFP: 150 $\mathrm{mM}$ salinity $\times$ Trichoderma $\times$ P biofertilizer; S300TOC: $300 \mathrm{mM}$ salinity $\times$ no Trichoderma $\times$ no biofertilizer; S300TOFN: $300 \mathrm{mM}$ salinity $\times$ no Trichoderma $\times$ N biofertilizer; S300TOFP: $300 \mathrm{mM}$ salinity $\times$ no Trichoderma $\times$ P biofertilizer; S300TC: $300 \mathrm{mM}$ salinity $\times$ Trichoderma $\times$ no biofertilizer; S300TFN: 300 $\mathrm{mM}$ salinity $\times$ Trichoderma $\times \mathrm{N}$ biofertilizer; S300TFP: $300 \mathrm{mM}$ salinity $\times$ Trichoderma $\times \mathrm{P}$ biofertilizer) . 


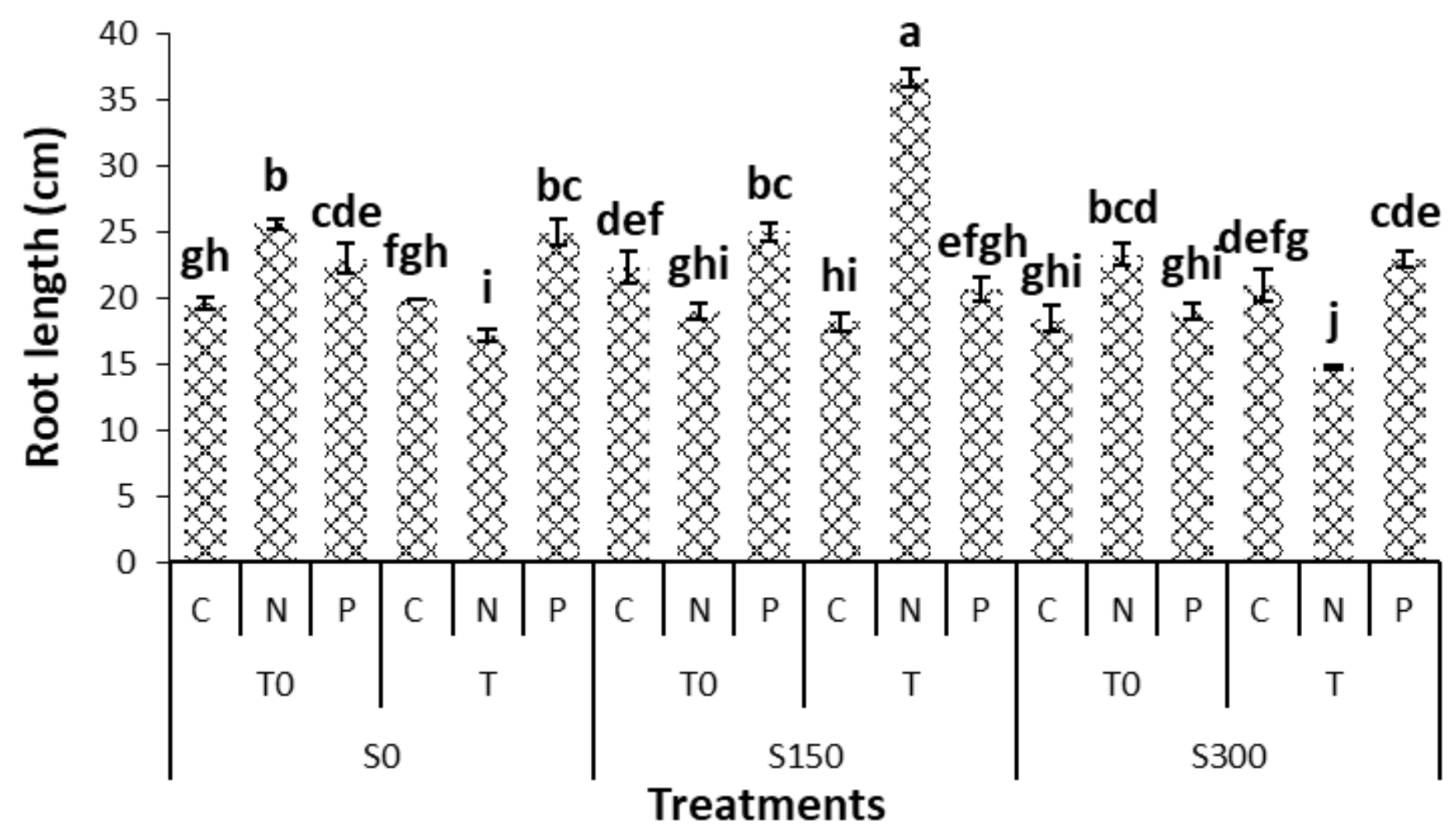

Figure 3

Means comparison for the root length of quinoa affected by salinity stress, biofertilizers, and Trichoderma. Unsimilar letters show significant difference at the $\mathrm{P}<0.01$ level. (SOTOC: no salinity $\times$ no Trichoderma $\times$ no biofertilizer; SOTOFN: no salinity $\times$ no Trichoderma $\times$ N biofertilizer; SOTOFP: no salinity $\times$ no Trichoderma $\times$ P biofertilizer; SOTC: no salinity $\times$ Trichoderma $\times$ no biofertilizer; SOTFN: no salinity $\times$ Trichoderma $\times \mathrm{N}$ biofertilizer; SOTFN: no salinity $\times$ Trichoderma $\times$ P biofertilizer; S150TOC: $150 \mathrm{mM}$ salinity $\times$ no Trichoderma $\times$ no biofertilizer; S150T0FN: $150 \mathrm{mM}$ salinity $\times$ no Trichoderma $\times \mathrm{N}$ biofertilizer; S150T0FP: $150 \mathrm{mM}$ salinity $\times$ no Trichoderma $\times$ P biofertilizer; S150TC: $150 \mathrm{mM}$ salinity $\times$ Trichoderma $\times$ no biofertilizer; S150TFN: $150 \mathrm{mM}$ salinity $\times$ Trichoderma $\times \mathrm{N}$ biofertilizer; S150TFP: 150 $\mathrm{mM}$ salinity $\times$ Trichoderma $\times$ P biofertilizer; S300TOC: $300 \mathrm{mM}$ salinity $\times$ no Trichoderma $\times$ no biofertilizer; S300TOFN: $300 \mathrm{mM}$ salinity $\times$ no Trichoderma $\times \mathrm{N}$ biofertilizer; S300T0FP: $300 \mathrm{mM}$ salinity $\times$ no Trichoderma $\times$ P biofertilizer; S300TC: 300 mM salinity $\times$ Trichoderma $\times$ no biofertilizer; S300TFN: 300 $\mathrm{mM}$ salinity $\times$ Trichoderma $\times \mathrm{N}$ biofertilizer; S300TFP: $300 \mathrm{mM}$ salinity $\times$ Trichoderma $\times \mathrm{P}$ biofertilizer) . 


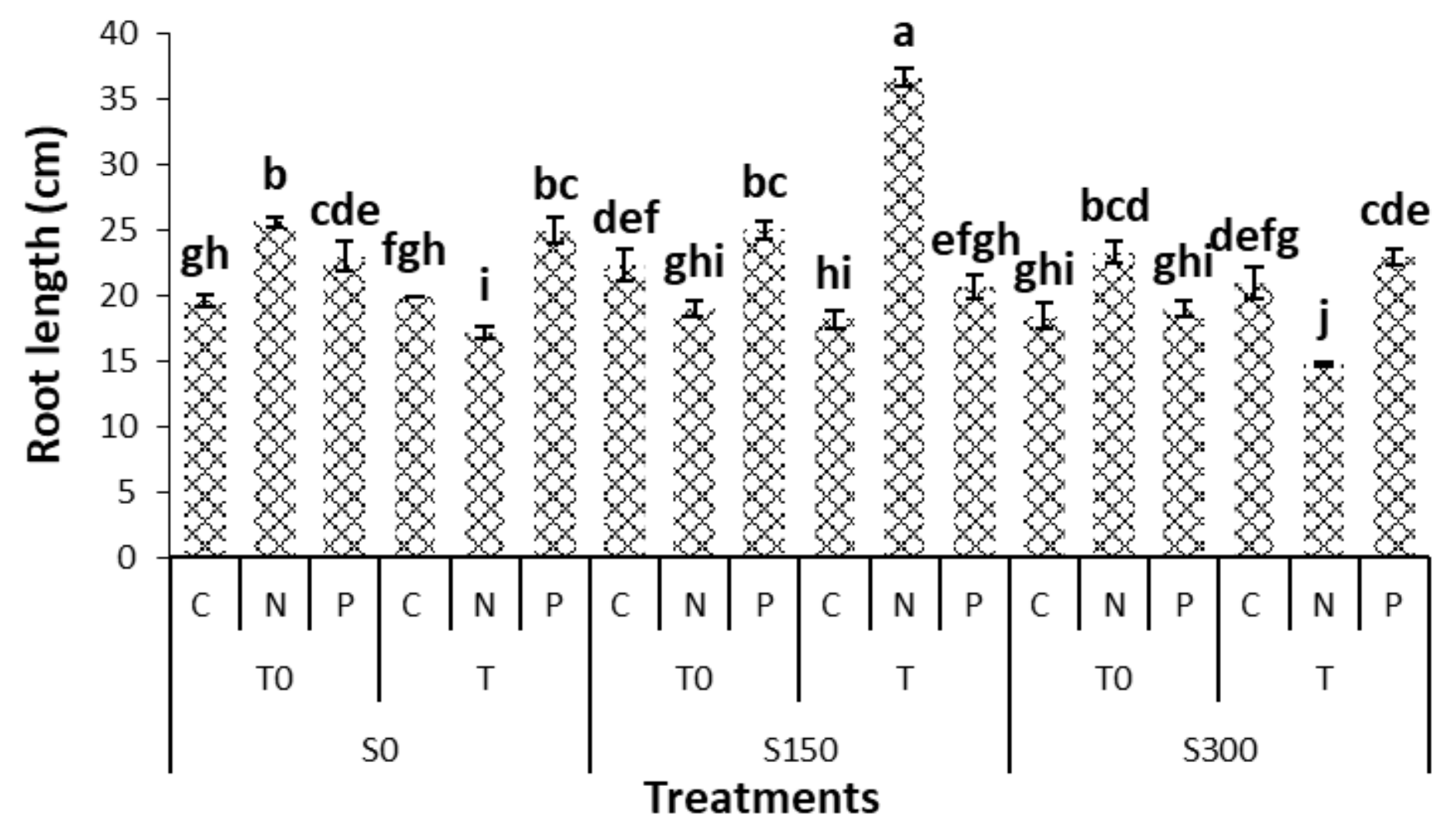

Figure 3

Means comparison for the root length of quinoa affected by salinity stress, biofertilizers, and Trichoderma. Unsimilar letters show significant difference at the $\mathrm{P}<0.01$ level. (SOTOC: no salinity $\times$ no Trichoderma $\times$ no biofertilizer; SOTOFN: no salinity $\times$ no Trichoderma $\times$ N biofertilizer; SOTOFP: no salinity $\times$ no Trichoderma $\times$ P biofertilizer; SOTC: no salinity $\times$ Trichoderma $\times$ no biofertilizer; SOTFN: no salinity $\times$ Trichoderma $\times \mathrm{N}$ biofertilizer; SOTFN: no salinity $\times$ Trichoderma $\times$ P biofertilizer; S150TOC: $150 \mathrm{mM}$ salinity $\times$ no Trichoderma $\times$ no biofertilizer; S150T0FN: $150 \mathrm{mM}$ salinity $\times$ no Trichoderma $\times \mathrm{N}$ biofertilizer; S150T0FP: $150 \mathrm{mM}$ salinity $\times$ no Trichoderma $\times$ P biofertilizer; S150TC: $150 \mathrm{mM}$ salinity $\times$ Trichoderma $\times$ no biofertilizer; S150TFN: $150 \mathrm{mM}$ salinity $\times$ Trichoderma $\times \mathrm{N}$ biofertilizer; S150TFP: 150 $\mathrm{mM}$ salinity $\times$ Trichoderma $\times$ P biofertilizer; S300TOC: $300 \mathrm{mM}$ salinity $\times$ no Trichoderma $\times$ no biofertilizer; S300TOFN: $300 \mathrm{mM}$ salinity $\times$ no Trichoderma $\times \mathrm{N}$ biofertilizer; S300T0FP: $300 \mathrm{mM}$ salinity $\times$ no Trichoderma $\times$ P biofertilizer; S300TC: 300 mM salinity $\times$ Trichoderma $\times$ no biofertilizer; S300TFN: 300 $\mathrm{mM}$ salinity $\times$ Trichoderma $\times \mathrm{N}$ biofertilizer; S300TFP: $300 \mathrm{mM}$ salinity $\times$ Trichoderma $\times \mathrm{P}$ biofertilizer) . 


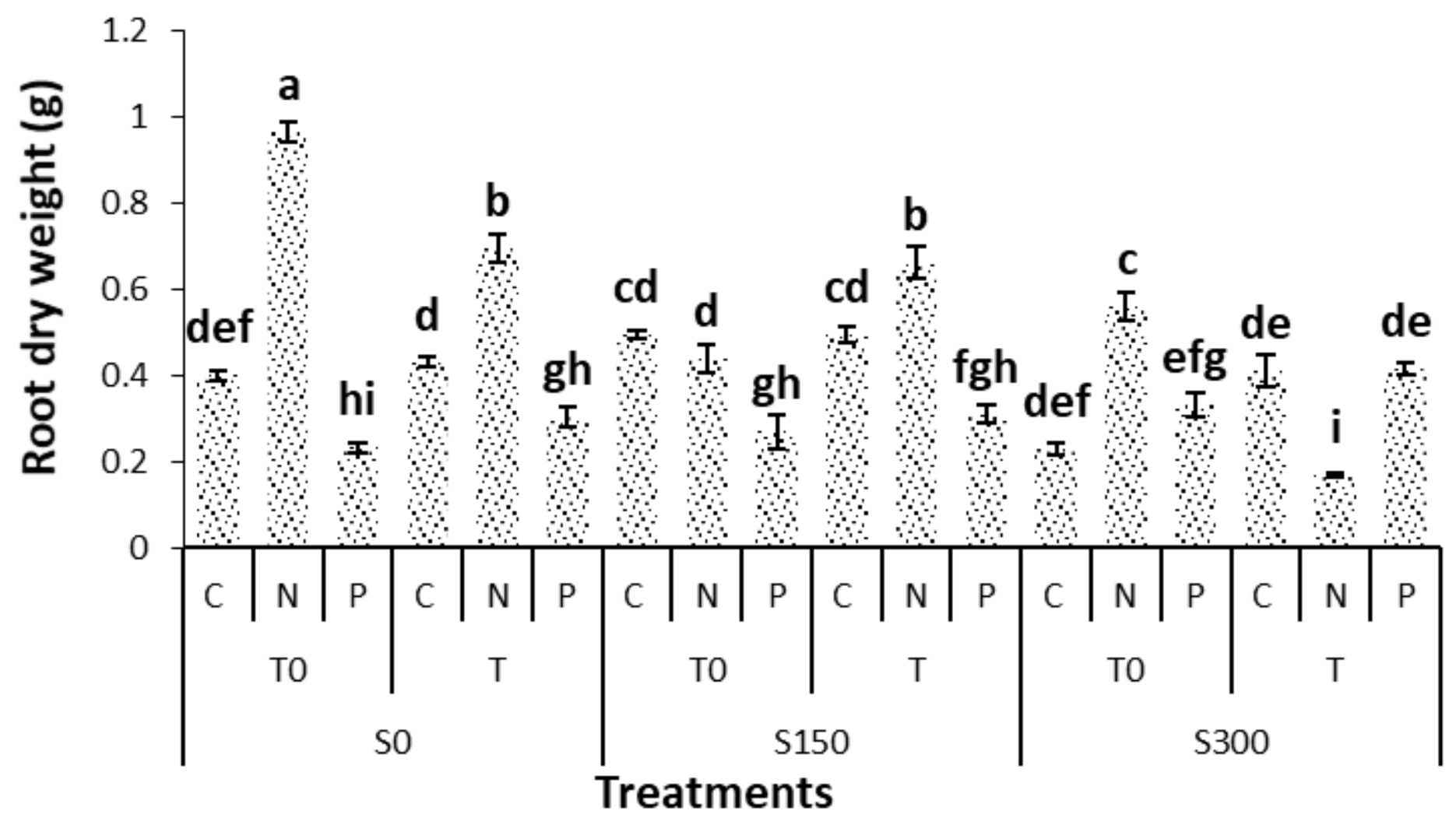

\section{Figure 4}

Means comparison for the root dry weight of quinoa affected by salinity stress, biofertilizers, and Trichoderma. Unsimilar letters show significant difference at the $P<0.01$ level. (SOTOC: no salinity $\times$ no Trichoderma $\times$ no biofertilizer; SOTOFN: no salinity $\times$ no Trichoderma $\times$ N biofertilizer; SOTOFP: no salinity $\times$ no Trichoderma $\times$ P biofertilizer; SOTC: no salinity $\times$ Trichoderma $\times$ no biofertilizer; SOTFN: no salinity $\times$ Trichoderma $\times \mathrm{N}$ biofertilizer; S0TFN: no salinity $\times$ Trichoderma $\times$ P biofertilizer; S150T0C: $150 \mathrm{mM}$ salinity $\times$ no Trichoderma $\times$ no biofertilizer; S150TOFN: $150 \mathrm{mM}$ salinity $\times$ no Trichoderma $\times \mathrm{N}$ biofertilizer; S150TOFP: $150 \mathrm{mM}$ salinity $\times$ no Trichoderma $\times$ P biofertilizer; S150TC: $150 \mathrm{mM}$ salinity $\times$ Trichoderma $\times$ no biofertilizer; S150TFN: $150 \mathrm{mM}$ salinity $\times$ Trichoderma $\times \mathrm{N}$ biofertilizer; S150TFP: 150 $\mathrm{mM}$ salinity $\times$ Trichoderma $\times \mathrm{P}$ biofertilizer; S300T0C: $300 \mathrm{mM}$ salinity $\times$ no Trichoderma $\times$ no biofertilizer; S300TOFN: $300 \mathrm{mM}$ salinity $\times$ no Trichoderma $\times$ N biofertilizer; S300T0FP: $300 \mathrm{mM}$ salinity $\times$ no Trichoderma $\times$ P biofertilizer; S300TC: $300 \mathrm{mM}$ salinity $\times$ Trichoderma $\times$ no biofertilizer; S300TFN: 300 $\mathrm{mM}$ salinity $\times$ Trichoderma $\times \mathrm{N}$ biofertilizer; S300TFP: $300 \mathrm{mM}$ salinity $\times$ Trichoderma $\times \mathrm{P}$ biofertilizer) . 


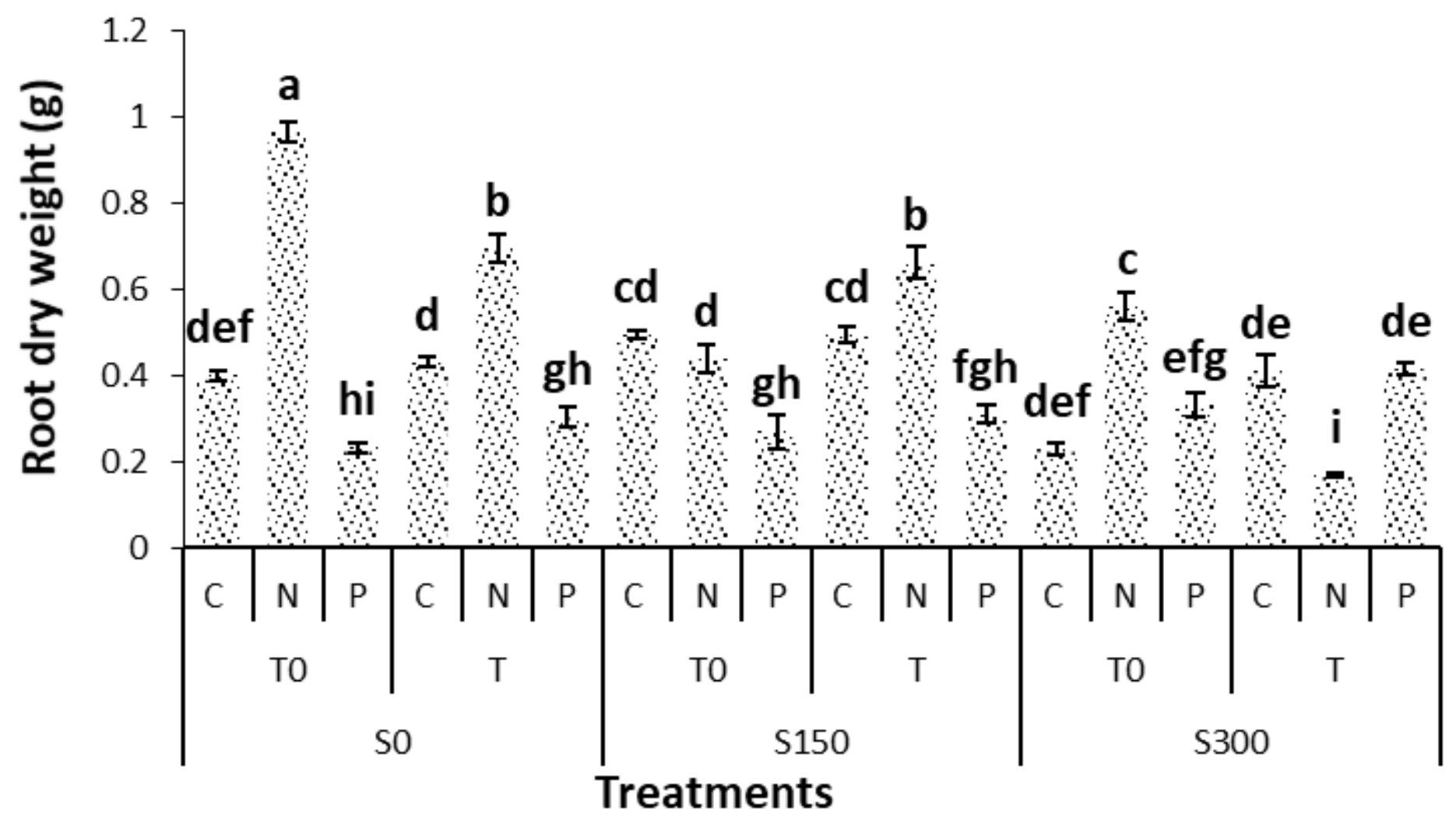

\section{Figure 4}

Means comparison for the root dry weight of quinoa affected by salinity stress, biofertilizers, and Trichoderma. Unsimilar letters show significant difference at the $P<0.01$ level. (SOTOC: no salinity $\times$ no Trichoderma $\times$ no biofertilizer; SOTOFN: no salinity $\times$ no Trichoderma $\times$ N biofertilizer; SOTOFP: no salinity $\times$ no Trichoderma $\times$ P biofertilizer; SOTC: no salinity $\times$ Trichoderma $\times$ no biofertilizer; SOTFN: no salinity $\times$ Trichoderma $\times \mathrm{N}$ biofertilizer; S0TFN: no salinity $\times$ Trichoderma $\times$ P biofertilizer; S150T0C: $150 \mathrm{mM}$ salinity $\times$ no Trichoderma $\times$ no biofertilizer; S150TOFN: $150 \mathrm{mM}$ salinity $\times$ no Trichoderma $\times \mathrm{N}$ biofertilizer; S150TOFP: $150 \mathrm{mM}$ salinity $\times$ no Trichoderma $\times$ P biofertilizer; S150TC: $150 \mathrm{mM}$ salinity $\times$ Trichoderma $\times$ no biofertilizer; S150TFN: $150 \mathrm{mM}$ salinity $\times$ Trichoderma $\times \mathrm{N}$ biofertilizer; S150TFP: 150 $\mathrm{mM}$ salinity $\times$ Trichoderma $\times \mathrm{P}$ biofertilizer; S300T0C: $300 \mathrm{mM}$ salinity $\times$ no Trichoderma $\times$ no biofertilizer; S300TOFN: $300 \mathrm{mM}$ salinity $\times$ no Trichoderma $\times$ N biofertilizer; S300T0FP: $300 \mathrm{mM}$ salinity $\times$ no Trichoderma $\times$ P biofertilizer; S300TC: $300 \mathrm{mM}$ salinity $\times$ Trichoderma $\times$ no biofertilizer; S300TFN: 300 $\mathrm{mM}$ salinity $\times$ Trichoderma $\times \mathrm{N}$ biofertilizer; S300TFP: $300 \mathrm{mM}$ salinity $\times$ Trichoderma $\times \mathrm{P}$ biofertilizer) . 


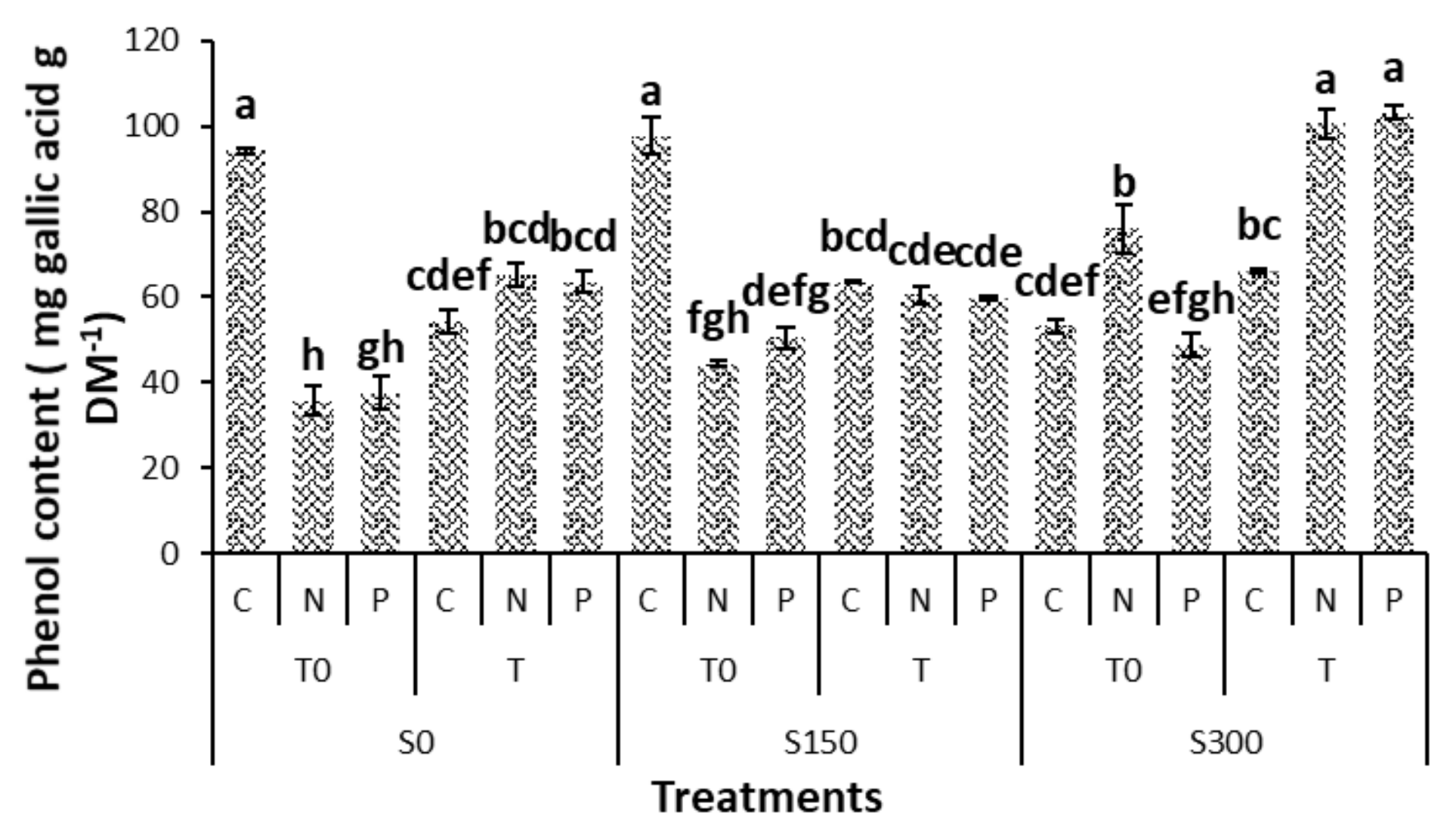

Figure 5

Means comparison for the phenol content of quinoa affected by salinity stress, biofertilizers, and Trichoderma. Unsimilar letters show significant difference at the $P<0.01$ level. (SOTOC: no salinity $\times$ no Trichoderma $\times$ no biofertilizer; SOTOFN: no salinity $\times$ no Trichoderma $\times$ N biofertilizer; SOTOFP: no salinity $\times$ no Trichoderma $\times$ P biofertilizer; SOTC: no salinity $\times$ Trichoderma $\times$ no biofertilizer; SOTFN: no salinity $\times$ Trichoderma $\times \mathrm{N}$ biofertilizer; SOTFN: no salinity $\times$ Trichoderma $\times$ P biofertilizer; S150TOC: $150 \mathrm{mM}$ salinity $\times$ no Trichoderma $\times$ no biofertilizer; S150T0FN: $150 \mathrm{mM}$ salinity $\times$ no Trichoderma $\times \mathrm{N}$ biofertilizer; S150T0FP: $150 \mathrm{mM}$ salinity $\times$ no Trichoderma $\times$ P biofertilizer; S150TC: $150 \mathrm{mM}$ salinity $\times$ Trichoderma $\times$ no biofertilizer; S150TFN: $150 \mathrm{mM}$ salinity $\times$ Trichoderma $\times \mathrm{N}$ biofertilizer; S150TFP: 150 $\mathrm{mM}$ salinity $\times$ Trichoderma $\times$ P biofertilizer; S300TOC: $300 \mathrm{mM}$ salinity $\times$ no Trichoderma $\times$ no biofertilizer; S300TOFN: $300 \mathrm{mM}$ salinity $\times$ no Trichoderma $\times$ N biofertilizer; S300T0FP: $300 \mathrm{mM}$ salinity $\times$ no Trichoderma $\times$ P biofertilizer; S300TC: $300 \mathrm{mM}$ salinity $\times$ Trichoderma $\times$ no biofertilizer; S300TFN: 300 $\mathrm{mM}$ salinity $\times$ Trichoderma $\times \mathrm{N}$ biofertilizer; S300TFP: $300 \mathrm{mM}$ salinity $\times$ Trichoderma $\times \mathrm{P}$ biofertilizer) . 


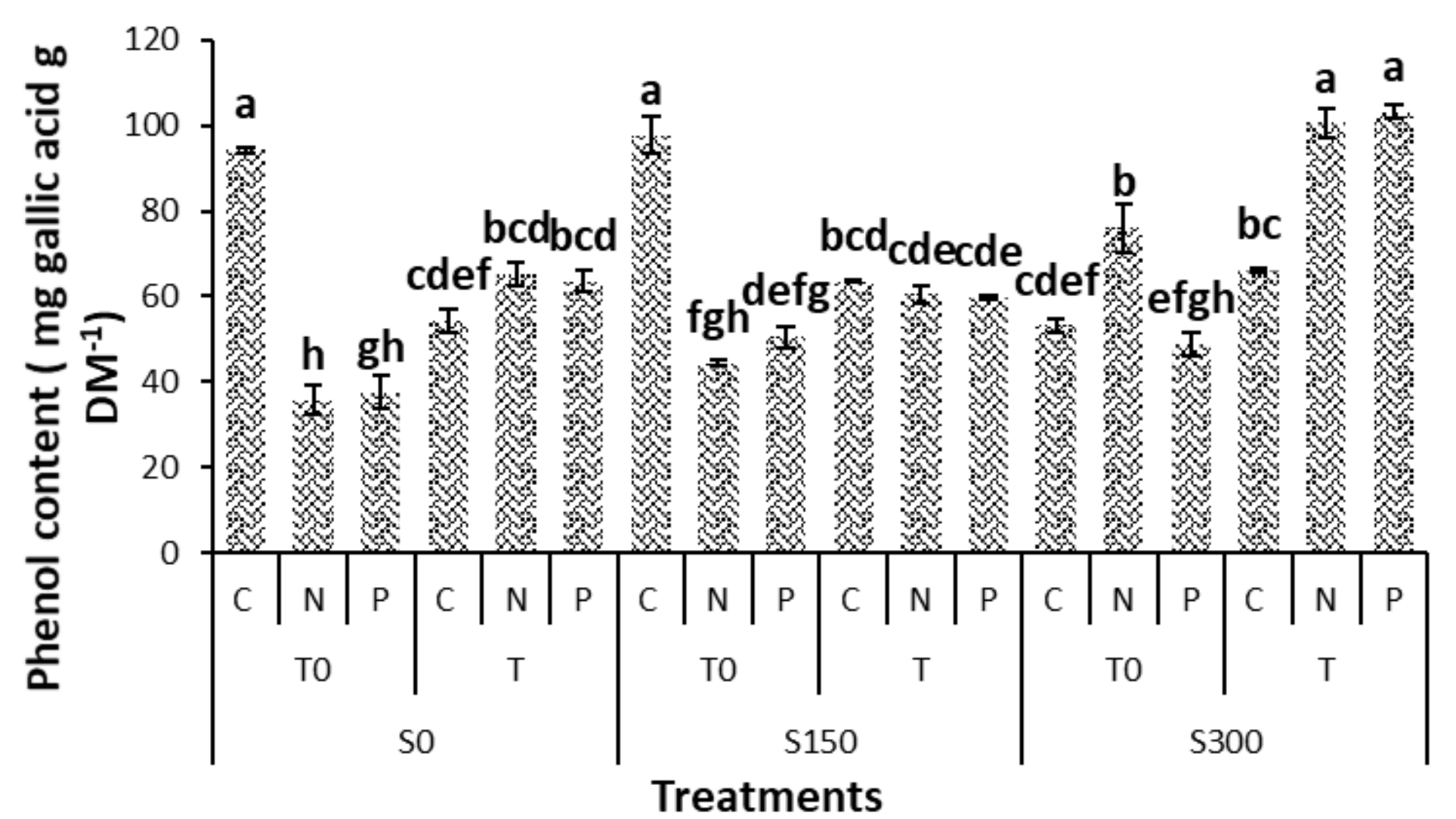

Figure 5

Means comparison for the phenol content of quinoa affected by salinity stress, biofertilizers, and Trichoderma. Unsimilar letters show significant difference at the $P<0.01$ level. (SOTOC: no salinity $\times$ no Trichoderma $\times$ no biofertilizer; SOTOFN: no salinity $\times$ no Trichoderma $\times$ N biofertilizer; SOTOFP: no salinity $\times$ no Trichoderma $\times$ P biofertilizer; SOTC: no salinity $\times$ Trichoderma $\times$ no biofertilizer; SOTFN: no salinity $\times$ Trichoderma $\times \mathrm{N}$ biofertilizer; SOTFN: no salinity $\times$ Trichoderma $\times$ P biofertilizer; S150TOC: $150 \mathrm{mM}$ salinity $\times$ no Trichoderma $\times$ no biofertilizer; S150T0FN: $150 \mathrm{mM}$ salinity $\times$ no Trichoderma $\times \mathrm{N}$ biofertilizer; S150T0FP: $150 \mathrm{mM}$ salinity $\times$ no Trichoderma $\times$ P biofertilizer; S150TC: $150 \mathrm{mM}$ salinity $\times$ Trichoderma $\times$ no biofertilizer; S150TFN: $150 \mathrm{mM}$ salinity $\times$ Trichoderma $\times \mathrm{N}$ biofertilizer; S150TFP: 150 $\mathrm{mM}$ salinity $\times$ Trichoderma $\times$ P biofertilizer; S300TOC: $300 \mathrm{mM}$ salinity $\times$ no Trichoderma $\times$ no biofertilizer; S300TOFN: $300 \mathrm{mM}$ salinity $\times$ no Trichoderma $\times$ N biofertilizer; S300T0FP: $300 \mathrm{mM}$ salinity $\times$ no Trichoderma $\times$ P biofertilizer; S300TC: $300 \mathrm{mM}$ salinity $\times$ Trichoderma $\times$ no biofertilizer; S300TFN: 300 $\mathrm{mM}$ salinity $\times$ Trichoderma $\times \mathrm{N}$ biofertilizer; S300TFP: $300 \mathrm{mM}$ salinity $\times$ Trichoderma $\times \mathrm{P}$ biofertilizer) . 


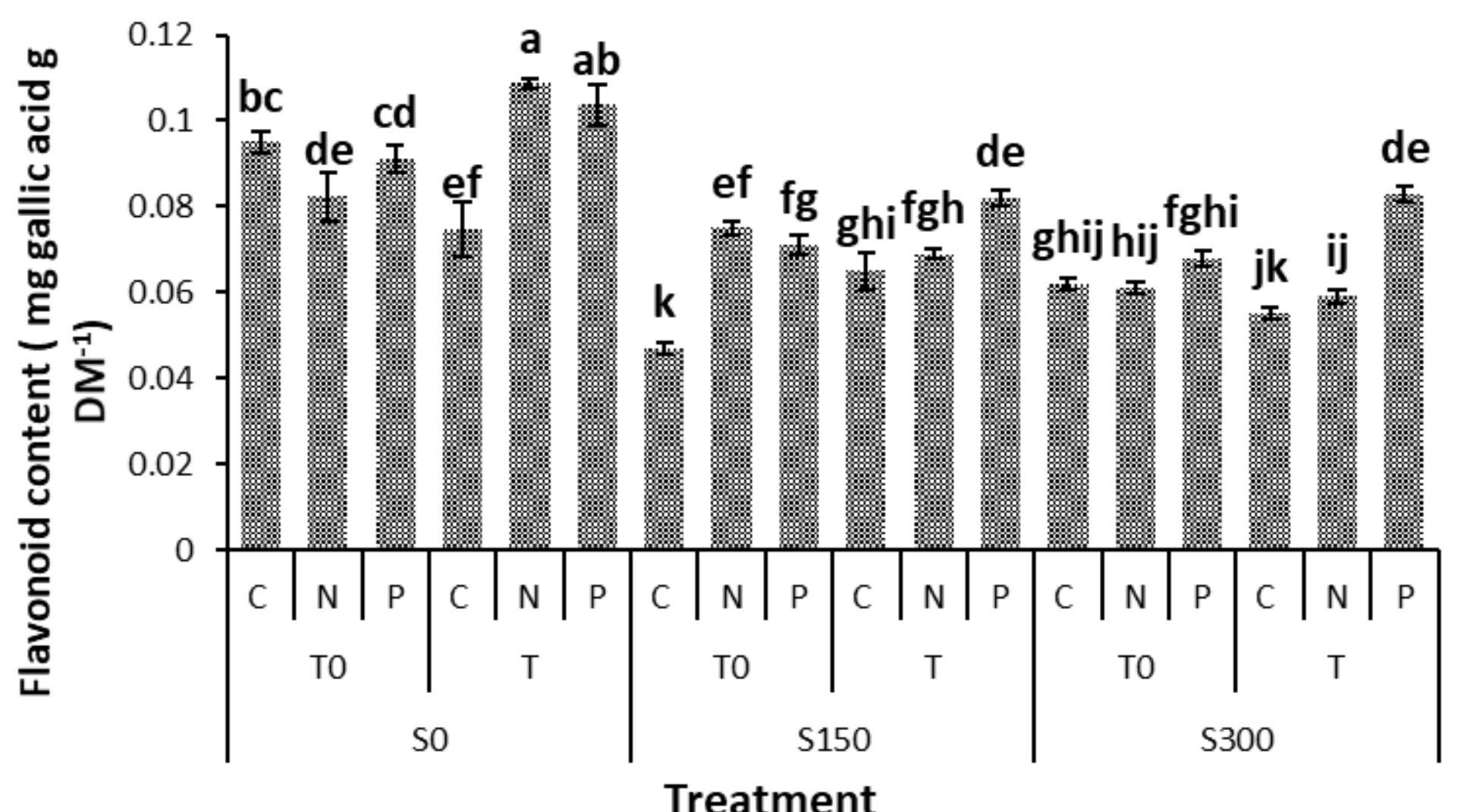

Figure 6

Means comparison for the flavonoid content of quinoa affected by salinity stress, biofertilizers, and Trichoderma. Unsimilar letters show significant difference at the $\mathrm{P}<0.01$ level. (SOTOC: no salinity $\times$ no Trichoderma $\times$ no biofertilizer; SOTOFN: no salinity $\times$ no Trichoderma $\times$ N biofertilizer; SOTOFP: no salinity $\times$ no Trichoderma $\times$ P biofertilizer; SOTC: no salinity $\times$ Trichoderma $\times$ no biofertilizer; SOTFN: no salinity $\times$ Trichoderma $\times \mathrm{N}$ biofertilizer; S0TFN: no salinity $\times$ Trichoderma $\times$ P biofertilizer; S150T0C: $150 \mathrm{mM}$ salinity $\times$ no Trichoderma $\times$ no biofertilizer; S150T0FN: $150 \mathrm{mM}$ salinity $\times$ no Trichoderma $\times \mathrm{N}$ biofertilizer; S150TOFP: $150 \mathrm{mM}$ salinity $\times$ no Trichoderma $\times$ P biofertilizer; S150TC: $150 \mathrm{mM}$ salinity $\times$ Trichoderma $\times$ no biofertilizer; S150TFN: $150 \mathrm{mM}$ salinity $\times$ Trichoderma $\times \mathrm{N}$ biofertilizer; S150TFP: 150 $\mathrm{mM}$ salinity $\times$ Trichoderma $\times$ P biofertilizer; S300TOC: $300 \mathrm{mM}$ salinity $\times$ no Trichoderma $\times$ no biofertilizer; S300TOFN: $300 \mathrm{mM}$ salinity $\times$ no Trichoderma $\times$ N biofertilizer; S300T0FP: $300 \mathrm{mM}$ salinity $\times$ no Trichoderma $\times$ P biofertilizer; S300TC: $300 \mathrm{mM}$ salinity $\times$ Trichoderma $\times$ no biofertilizer; S300TFN: 300 $\mathrm{mM}$ salinity $\times$ Trichoderma $\times \mathrm{N}$ biofertilizer; S300TFP: $300 \mathrm{mM}$ salinity $\times$ Trichoderma $\times \mathrm{P}$ biofertilizer) . 


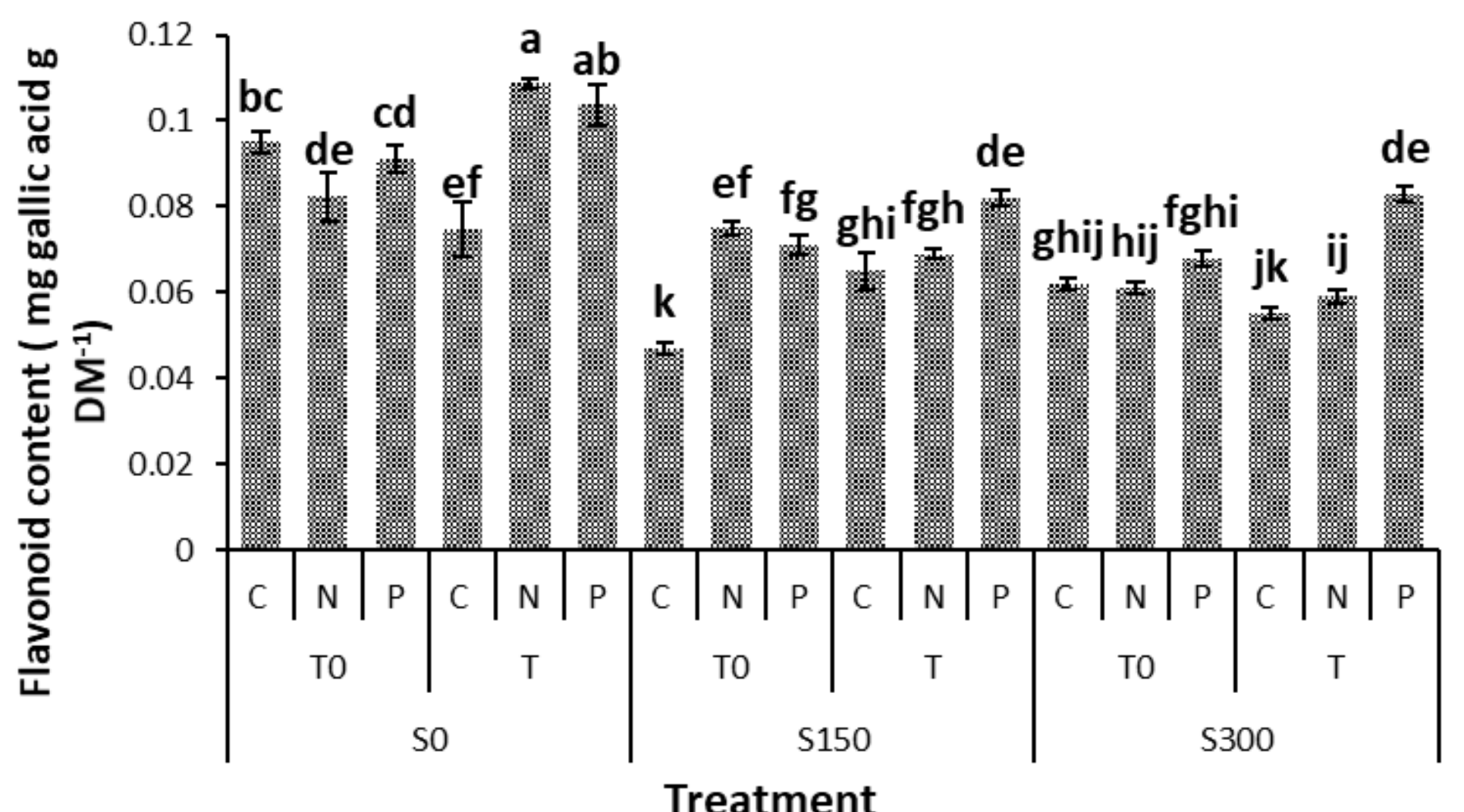

Figure 6

Means comparison for the flavonoid content of quinoa affected by salinity stress, biofertilizers, and Trichoderma. Unsimilar letters show significant difference at the $\mathrm{P}<0.01$ level. (SOTOC: no salinity $\times$ no Trichoderma $\times$ no biofertilizer; SOTOFN: no salinity $\times$ no Trichoderma $\times$ N biofertilizer; SOTOFP: no salinity $\times$ no Trichoderma $\times$ P biofertilizer; SOTC: no salinity $\times$ Trichoderma $\times$ no biofertilizer; SOTFN: no salinity $\times$ Trichoderma $\times \mathrm{N}$ biofertilizer; S0TFN: no salinity $\times$ Trichoderma $\times$ P biofertilizer; S150T0C: $150 \mathrm{mM}$ salinity $\times$ no Trichoderma $\times$ no biofertilizer; S150T0FN: $150 \mathrm{mM}$ salinity $\times$ no Trichoderma $\times \mathrm{N}$ biofertilizer; S150TOFP: $150 \mathrm{mM}$ salinity $\times$ no Trichoderma $\times$ P biofertilizer; S150TC: $150 \mathrm{mM}$ salinity $\times$ Trichoderma $\times$ no biofertilizer; S150TFN: $150 \mathrm{mM}$ salinity $\times$ Trichoderma $\times \mathrm{N}$ biofertilizer; S150TFP: 150 $\mathrm{mM}$ salinity $\times$ Trichoderma $\times$ P biofertilizer; S300TOC: $300 \mathrm{mM}$ salinity $\times$ no Trichoderma $\times$ no biofertilizer; S300TOFN: $300 \mathrm{mM}$ salinity $\times$ no Trichoderma $\times$ N biofertilizer; S300T0FP: $300 \mathrm{mM}$ salinity $\times$ no Trichoderma $\times$ P biofertilizer; S300TC: $300 \mathrm{mM}$ salinity $\times$ Trichoderma $\times$ no biofertilizer; S300TFN: 300 $\mathrm{mM}$ salinity $\times$ Trichoderma $\times \mathrm{N}$ biofertilizer; S300TFP: $300 \mathrm{mM}$ salinity $\times$ Trichoderma $\times \mathrm{P}$ biofertilizer) . 

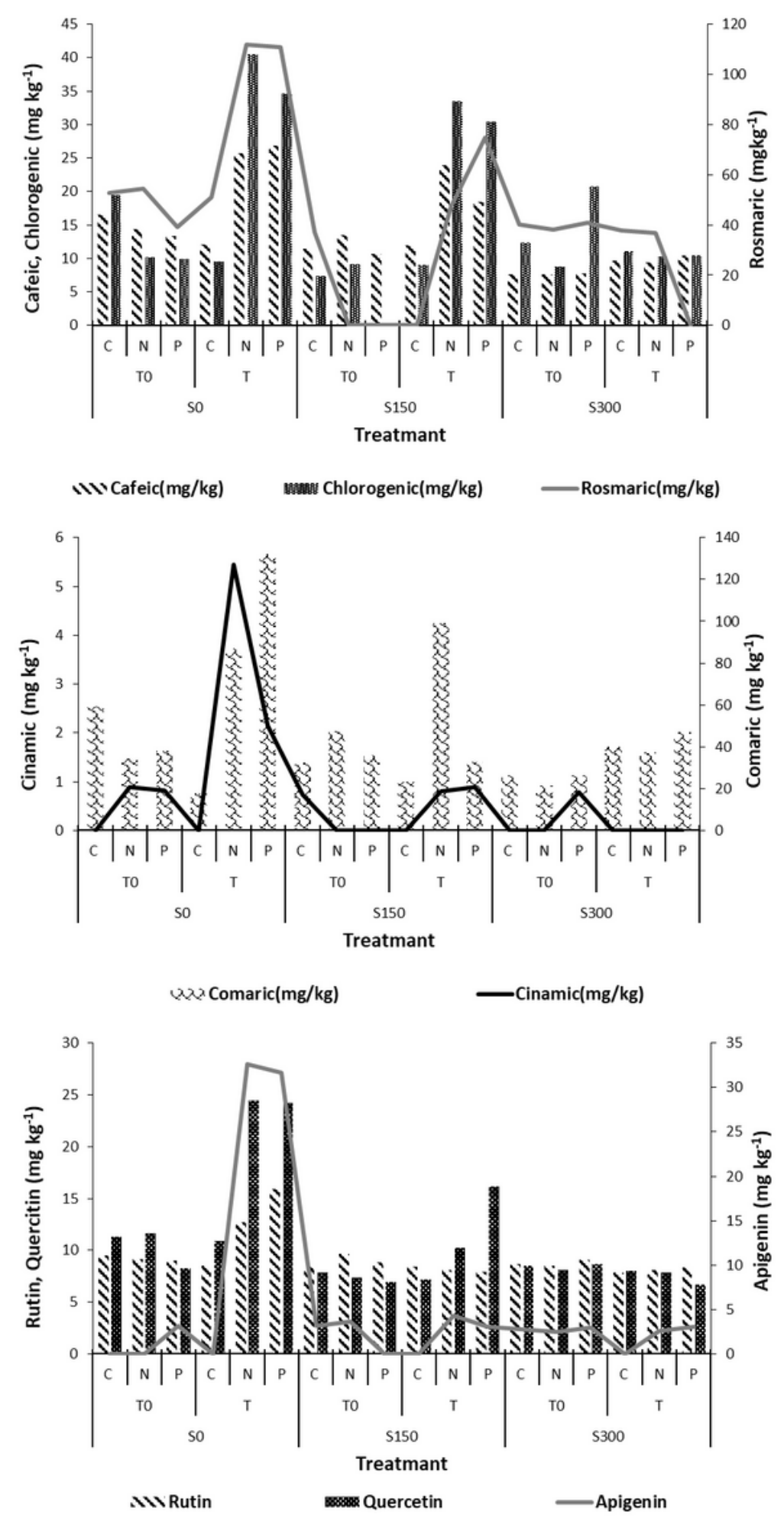

Figure 7

HPLC for the (caffeic acid, rosmarinic acid, chlorogenic acid, coumaric acid, cinnamic acid, rutin, quercetin and apigenin) of quinoa affected by salinity stress, biofertilizers, and Trichoderma. (SOTOC: no salinity $\times$ no Trichoderma $\times$ no biofertilizer; SOTOFN: no salinity $\times$ no Trichoderma $\times$ N biofertilizer; SOTOFP: no salinity $\times$ no Trichoderma $\times$ P biofertilizer; SOTC: no salinity $\times$ Trichoderma $\times$ no biofertilizer; SOTFN: no salinity $\times$ Trichoderma $\times \mathrm{N}$ biofertilizer; SOTFN: no salinity $\times$ Trichoderma $\times \mathrm{P}$ biofertilizer; 
S150T0C: $150 \mathrm{mM}$ salinity $\times$ no Trichoderma $\times$ no biofertilizer; S150T0FN: $150 \mathrm{mM}$ salinity $\times$ no Trichoderma $\times \mathrm{N}$ biofertilizer; S150TOFP: $150 \mathrm{mM}$ salinity $\times$ no Trichoderma $\times$ P biofertilizer; S150TC: 150 $\mathrm{mM}$ salinity $\times$ Trichoderma $\times$ no biofertilizer; S150TFN: $150 \mathrm{mM}$ salinity $\times$ Trichoderma $\times \mathrm{N}$ biofertilizer; S150TFP: $150 \mathrm{mM}$ salinity $\times$ Trichoderma $\times$ P biofertilizer; S300T0C: $300 \mathrm{mM}$ salinity $\times$ no Trichoderma $\times$ no biofertilizer; S300TOFN: $300 \mathrm{mM}$ salinity $\times$ no Trichoderma $\times$ N biofertilizer; S300TOFP: $300 \mathrm{mM}$ salinity $\times$ no Trichoderma $\times$ P biofertilizer; S300TC: $300 \mathrm{mM}$ salinity $\times$ Trichoderma $\times$ no biofertilizer; S300TFN: $300 \mathrm{mM}$ salinity $\times$ Trichoderma $\times \mathrm{N}$ biofertilizer; S300TFP: $300 \mathrm{mM}$ salinity $\times$ Trichoderma $\times \mathrm{P}$ biofertilizer). 

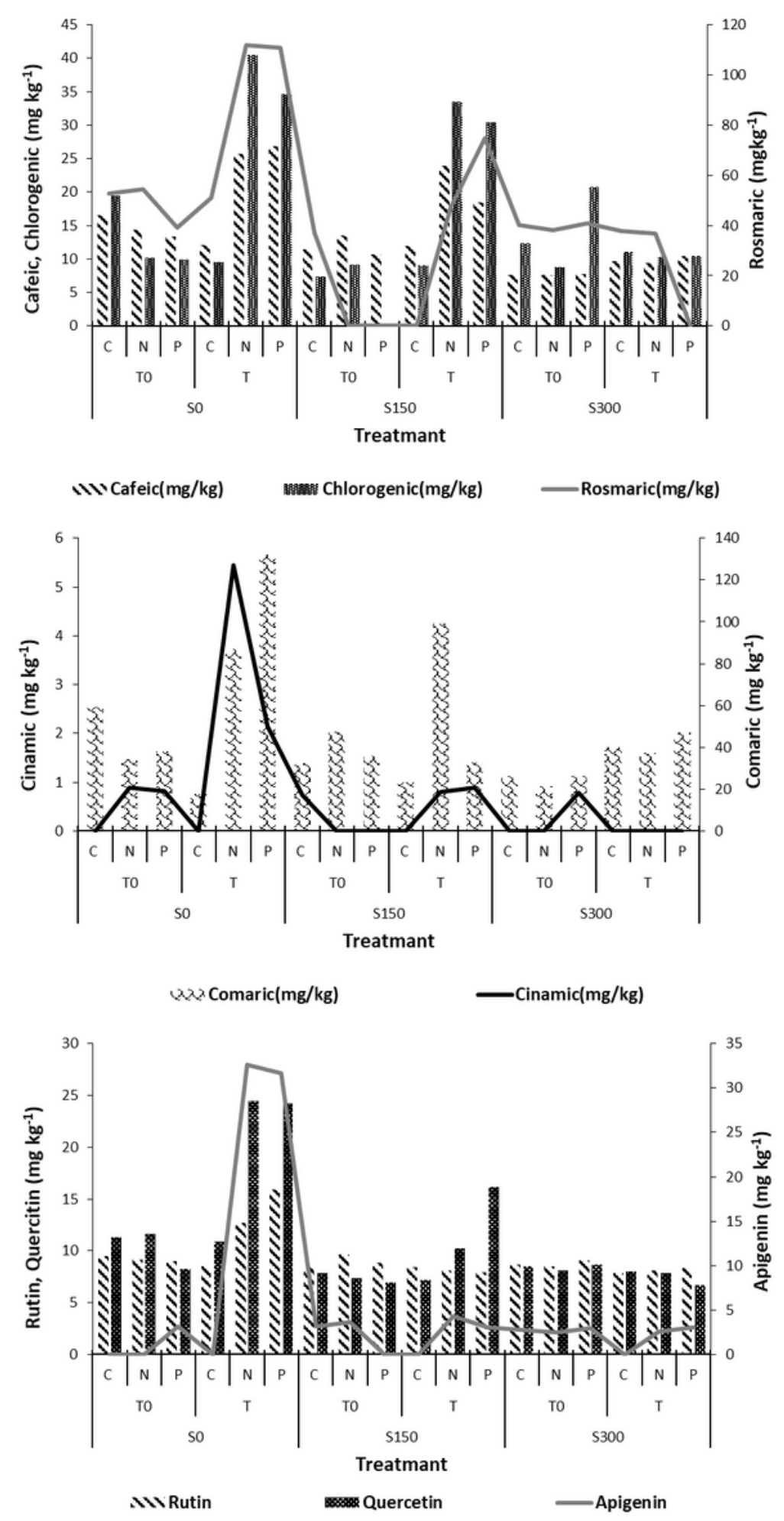

Figure 7

HPLC for the (caffeic acid, rosmarinic acid, chlorogenic acid, coumaric acid, cinnamic acid, rutin, quercetin and apigenin) of quinoa affected by salinity stress, biofertilizers, and Trichoderma. (SOTOC: no salinity $\times$ no Trichoderma $\times$ no biofertilizer; SOTOFN: no salinity $\times$ no Trichoderma $\times$ N biofertilizer; SOTOFP: no salinity $\times$ no Trichoderma $\times$ P biofertilizer; SOTC: no salinity $\times$ Trichoderma $\times$ no biofertilizer; SOTFN: no salinity $\times$ Trichoderma $\times \mathrm{N}$ biofertilizer; SOTFN: no salinity $\times$ Trichoderma $\times \mathrm{P}$ biofertilizer; 
S150T0C: $150 \mathrm{mM}$ salinity $\times$ no Trichoderma $\times$ no biofertilizer; S150T0FN: $150 \mathrm{mM}$ salinity $\times$ no Trichoderma $\times$ N biofertilizer; S150TOFP: $150 \mathrm{mM}$ salinity $\times$ no Trichoderma $\times$ P biofertilizer; S150TC: 150 $\mathrm{mM}$ salinity $\times$ Trichoderma $\times$ no biofertilizer; S150TFN: $150 \mathrm{mM}$ salinity $\times$ Trichoderma $\times \mathrm{N}$ biofertilizer; S150TFP: $150 \mathrm{mM}$ salinity $\times$ Trichoderma $\times$ P biofertilizer; S300T0C: $300 \mathrm{mM}$ salinity $\times$ no Trichoderma $\times$ no biofertilizer; S300TOFN: $300 \mathrm{mM}$ salinity $\times$ no Trichoderma $\times$ N biofertilizer; S300TOFP: $300 \mathrm{mM}$ salinity $\times$ no Trichoderma $\times$ P biofertilizer; S300TC: $300 \mathrm{mM}$ salinity $\times$ Trichoderma $\times$ no biofertilizer; S300TFN: $300 \mathrm{mM}$ salinity $\times$ Trichoderma $\times \mathrm{N}$ biofertilizer; S300TFP: $300 \mathrm{mM}$ salinity $\times$ Trichoderma $\times \mathrm{P}$ biofertilizer). 